Atmos. Chem. Phys. Discuss., 9, 18793-18838, 2009 www.atmos-chem-phys-discuss.net/9/18793/2009/ (C) Author(s) 2009. This work is distributed under the Creative Commons Attribution 3.0 License.

This discussion paper is/has been under review for the journal Atmospheric Chemistry and Physics $(A C P)$. Please refer to the corresponding final paper in $A C P$ if available.

\title{
Peroxy radicals and ozone photochemistry in air masses undergoing long-range transport
}

\section{ACPD}

9, 18793-18838, 2009

Peroxy radicals and ozone

photochemistry in air masses

A. E. Parker et al.

Title Page

Abstract

Introduction

Conclusions

Tables

References

Figures

14

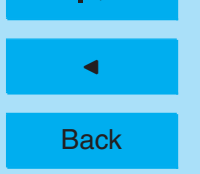

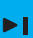

Close

${ }^{2}$ Department of Chemistry, University of Leicester, Leicester, LE1 7RH, UK

${ }^{3}$ Department of Chemistry, University of York, York, UK

${ }^{4}$ School of Chemistry, National Centre for Atmospheric Science (NCAS), University of Leeds, Leeds, LS2 9JT, UK

${ }^{5}$ Department of Meteorology, University of Reading, UK

${ }^{6}$ Norsk Institutt for Luftforskning, P.O. Box 100, 2027 Kjeller, Norway

Full Screen / Esc

Printer-friendly Version

Interactive Discussion 
* now at: PC2A, Université des Sciences et Technologies de Lille, France

${ }^{*}$ now at: MPI, Mainz, Germany

${ }^{* * *}$ now at: Department of Chemistry Univ of Reading, Reading, UK

Received: 10 August 2009 - Accepted: 26 August 2009 - Published: 10 September 2009

Correspondence to: P. S. Monks (psm7@le.ac.uk)

Published by Copernicus Publications on behalf of the European Geosciences Union.

9, 18793-18838, 2009

\section{Peroxy radicals and ozone \\ photochemistry in air masses}

A. E. Parker et al.

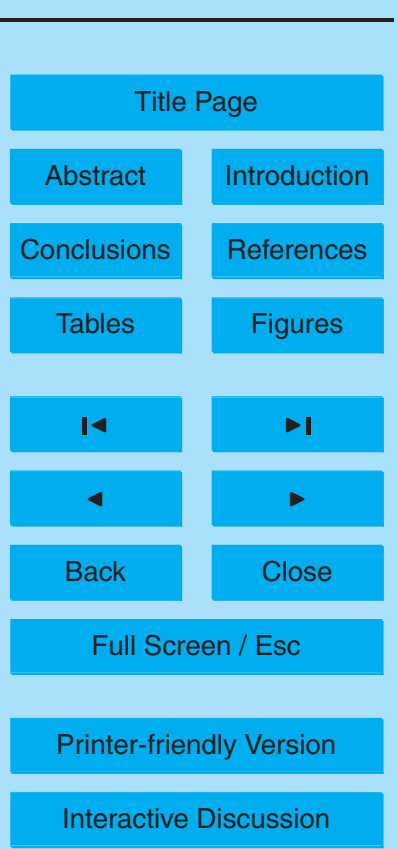




\section{Abstract}

Concentrations of peroxy radicals $\left(\mathrm{HO}_{2}+\Sigma_{i} \mathrm{R}_{i} \mathrm{O}_{2}\right)$ in addition to other trace gases were measured onboard the UK Meteorological Office/Natural Environment Research Council British Aerospace 146-300 atmospheric research aircraft during the Intercontinental

5 Transport of Ozone and Precursors (ITOP) campaign based at Horta Airport, Faial, Azores $\left(38.58^{\circ} \mathrm{N}, 28.72^{\circ} \mathrm{W}\right)$ in July/August 2004 . The overall peroxy radical altitude profile displays an increase with altitude that is likely to have been impacted by the effects of long-range transport. The peroxy radical altitude profile for air classified as of marine origin shows no discernable altitude profile. A range of air-masses were intercepted with varying source signatures, including those with aged American and Asian signatures, air-masses of biomass burning origin, and those that originated from the east coast of the United States. Enhanced peroxy radical concentrations have been observed within this range of air-masses indicating that long-range transported airmasses traversing the Atlantic show significant photochemical activity. The net ozone production at clear sky limit is in general negative, and as such the summer mid-Atlantic troposphere is at limit net ozone destructive. However, there is clear evidence of positive ozone production even at clear sky limit within air masses undergoing long-range transport, and during ITOP especially between 5 and $5.5 \mathrm{~km}$, which in the main corresponds to a flight that extensively sampled air with a biomass burning signature. Ozone production was $\mathrm{NO}_{\mathrm{x}}$ limited throughout ITOP, as evidenced by a good correlation $\left(r^{2}=0.72\right)$ between $\mathrm{P}\left(\mathrm{O}_{3}\right)$ and NO. Strong positive net ozone production has also been seen in varying source signature air-masses undergoing long-range transport, including but not limited to low-level export events, and export from the east coast of the United States.

\section{Peroxy radicals and ozone \\ photochemistry in air masses}

A. E. Parker et al.

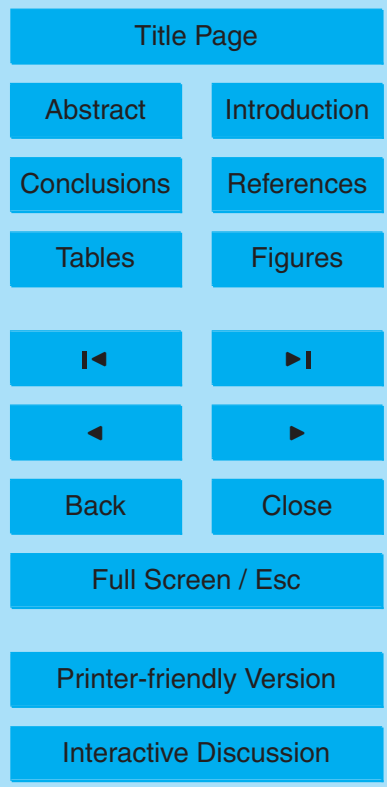




\section{Introduction}

In recent years the importance of long-range transport of pollutants and precursor species to the composition of the troposphere remote to the source region has been recognised (Fehsenfeld et al., 1996; Penkett et al., 1998). Trace gases and aerosols 5 can be transported over intercontinental distances (Duncan and Bey, 2004; Derwent et al., 2004; Stohl and Trickl, 1999; Wild and Akimoto, 2001). The relevance of ozone and its precursors to atmospheric pollution is well known, and progress has been made in the measurements of many trace gases associated with ozone, although there remain key uncertainties in the budgets of these species. Ozone has a lifetime of weeks to 10 several months in the troposphere (Liu et al., 1987) and can be transported great distances in that time, whilst the emission of $\mathrm{NO}_{\mathrm{x}}$ and VOCs can lead to further ozone production downstream of the source with subsequent impact on the formulation of local air quality budgets (e.g., Li et al., 2002).

Peroxy radicals $\left(\mathrm{HO}_{2}+\Sigma_{i} \mathrm{R}_{i} \mathrm{O}_{2}\right)$ are key intermediates and chain carriers in the photochemical cycling of ozone in the troposphere (Monks, 2005). Peroxy radicals are formed via the oxidation of anthropogenic and biogenic species in the atmosphere such as $\mathrm{CO}, \mathrm{CH}_{4}$ and other organic compounds. Ozone is produced via the peroxy radical catalysed oxidation of $\mathrm{NO}$ to $\mathrm{NO}_{2}$ and subsequent photolysis of $\mathrm{NO}_{2}$, whilst ozone can also be destroyed through reaction with $\mathrm{HO}_{2}$. Owing to the short lifetime of peroxy radicals $\left(\mathrm{HO}_{2}\right.$ has a lifetime on the order of a minute in clean air, much less than a minute in polluted air - Monks, 2005), they give a good indication in combination with NO of in-situ photochemical ozone production and loss. In addition, the selfand cross-reactions of peroxy radicals to form peroxides are a major sink for $\mathrm{HO}_{2}$ and $\mathrm{OH}$ (Reeves and Penkett, 2003). The measurement of peroxy radicals thus remains of central importance in atmospheric chemistry, and rapid progress has been made in recent years with many deployments utilising various techniques for both ground and airborne studies (Mihele and Hastie, 2003; Cantrell et al., 2003a; Salisbury et al., 2001; Sommariva et al., 2004; Edwards et al., 2003; Green et al., 2003; Mihelcic et al., 2003;

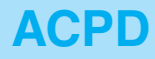

9, 18793-18838, 2009

\section{Peroxy radicals and ozone \\ photochemistry in air masses}

A. E. Parker et al.

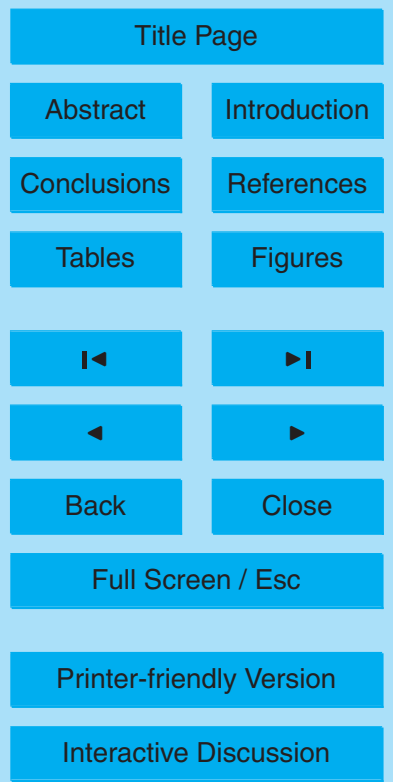


Heard and Pilling, 2003; Green et al., 2006; Hanke et al., 2002).

The Intercontinental Transport of Ozone and Precursors (ITOP-UK) campaign took place during July/August 2004 and constituted the UK contribution to the International Consortium for Atmospheric Research on Transport and Transformation (ICARTT). The 5 UK Meteorological Office/Natural Environment Research Council British Aerospace 146-300 atmospheric research aircraft was deployed from Horta Airport, Faial, Azores $\left(38.58^{\circ} \mathrm{N}, 28.72^{\circ} \mathrm{W}\right)$ and flew a total of 12 science flights over a 22-day period. A full description of the flights and instrument payload of the BAe 146 has been given elsewhere (Fehsenfeld et al., 2006) whilst an overview of the ITOP campaign is given in 10 Lewis et al. (Lewis et al., 2006). This paper details the measurements of the sum of peroxy radicals $\left(\mathrm{HO}_{2}+\Sigma_{i} \mathrm{R}_{i} \mathrm{O}_{2}\right)$ using the PEroxy Radical Chemical Amplification (PERCA) technique. The data have been analysed to investigate the oxidant production in air masses undergoing long-range transport.

\section{Experimental details}

\subsection{The PERCA instrument}

The Chemical Amplification technique was introduced by Cantrell in the early 1980s (Cantrell and Stedman, 1982; Cantrell et al., 1984) and has been widely deployed since then (Cantrell et al., 1993; Mihele and Hastie, 2003; Monks et al., 1998; Zanis et al., 2000; Green et al., 2006), although there is only one previous publication of aircraft measurements using the technique (Green et al., 2003). The PERCA technique utilises the radical catalysed conversion of $\mathrm{NO}$ and $\mathrm{CO}$ into $\mathrm{NO}_{2}$ and $\mathrm{CO}_{2}$ respectively via addition of $\mathrm{NO}(3 \mathrm{ppmv})$ and $\mathrm{CO}(6 \% \mathrm{v} / \mathrm{v})$ to the inlet region. $\mathrm{NO}_{2}$ is subsequently detected via aqueous luminol (5-amino-2,3-dihydro-1,4-pthalazinedione) solution chemiluminescence at $\lambda=424 \mathrm{~nm}$ with an improved LMA-3 detector as described by Green et al.

25 (Green et al., 2006).

$$
\mathrm{RO}_{2}+\mathrm{NO} \rightarrow \mathrm{RO}+\mathrm{NO}_{2}
$$

\section{Peroxy radicals and ozone \\ photochemistry in air masses}

A. E. Parker et al.

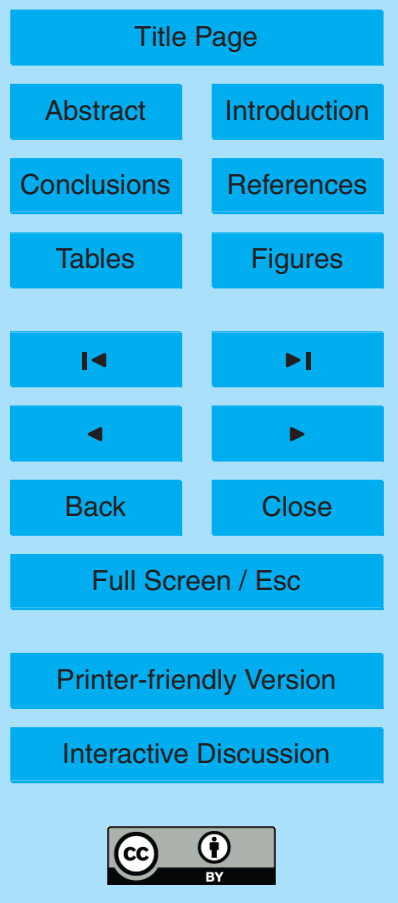




$$
\begin{array}{ll} 
& \mathrm{RO}+\mathrm{O}_{2} \rightarrow \mathrm{R}^{\prime} \mathrm{CHO}+\mathrm{HO}_{2} \\
& \mathrm{HO}_{2}+\mathrm{NO} \rightarrow \mathrm{OH}+\mathrm{NO}_{2} \\
& \mathrm{OH}+\mathrm{CO} \rightarrow \mathrm{H}+\mathrm{CO}_{2} \\
& \mathrm{H}+\mathrm{O}_{2}+\mathrm{M} \rightarrow \mathrm{HO}_{2}+\mathrm{M} \\
5 & \mathrm{CO}+\mathrm{NO}+\mathrm{O}_{2} \rightarrow \mathrm{CO}_{2}+\mathrm{NO}_{2}
\end{array}
$$

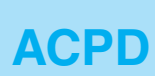

9, 18793-18838, 2009

The yield of $\mathrm{NO}_{2}$ is equal to $\mathrm{CL} \times\left[\mathrm{HO}_{2}+\Sigma_{i} \mathrm{R}_{i} \mathrm{O}_{2}+\Sigma_{i} \mathrm{R}_{i} \mathrm{O}+\mathrm{OH}\right]$, where $\mathrm{CL}$ is the chain length, i.e. the number of $\mathrm{HO}_{2} / \mathrm{OH}$ conversion cycles that occur before termination.

A significant background $\mathrm{NO}_{2}$ signal is also observed from other sources such as the reaction of ozone with the reagent NO. Assuming a chain length of 100 (i.e. each 10 radical molecule produces 100 molecules of $\mathrm{NO}_{2}$ ) and a radical mixing ratio of $20 \mathrm{pptv}$, the radical chain cycle would produce $2 \mathrm{ppbv}$ of $\mathrm{NO}_{2}$. Under polluted conditions, ambient ozone could contribute up to $100 \mathrm{ppbv}$ of $\mathrm{NO}_{2}$. Consequently, it is necessary to periodically measure only the background $\mathrm{NO}_{2}$ produced by means other than peroxy radical conversion. This is achieved by injecting $\mathrm{CO}$ downstream of the NO injection 15 point. $\mathrm{OH}$ produced as a result of Reaction (3) cannot be recycled into $\mathrm{HO}_{2}$ as Reactions (4) and (5) do not take place, and instead some $\mathrm{OH}$ reacts with $\mathrm{NO}$ in a chain termination step (Reaction 7), whilst remaining radicals are lost to the walls of the inlet.

$$
\mathrm{OH}+\mathrm{NO}+\mathrm{M} \rightarrow \mathrm{HONO}+\mathrm{M}
$$

A flow of inert gas (nitrogen) is added in place of the $\mathrm{CO}$ so that in amplification mode $20 \mathrm{NO}$ and $\mathrm{CO}$ are injected upstream of $\mathrm{N}_{2}$, and in background mode $\mathrm{NO}$ and $\mathrm{N}_{2}$ are injected upstream of $\mathrm{CO}$. This ensures that the properties of the sample gas flow remain unchanged in both operation modes. It also helps reduce pressure pulsing in the detected signal and allows the flows to settle again more quickly after switching. The sensitivity of the PERCA instrument to humidity is well known (Mihele and Hastie, 25 1998; Mihele et al., 1999) and consequently a water correction as per Salisbury et al. (Salisbury et al., 2002) has been applied to all data in this study. This correction is relatively small out of the boundary layer as humidity is generally low. The average 18798

Peroxy radicals and ozone

photochemistry in air masses

A. E. Parker et al.

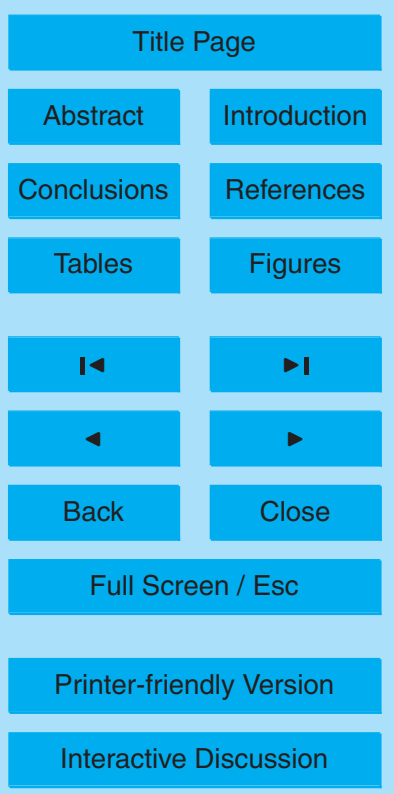

Interactive Discussion 
peroxy radical value increases from $18-29 \mathrm{pptv}$ under $2.5 \mathrm{~km}$ with the average radical value over $2.5 \mathrm{~km}$ only increasing from $35-41 \mathrm{pptv}$ when the correction is applied.

\subsection{Aircraft Inlet System}

In the previous aircraft deployment of a PERCA instrument (Green et al., 2003), a sin5 gle inlet was connected to the air sample pipe on the former UK Meteorological Office Hercules C-130, whereas the instrument deployed during ITOP was a dual-channel instrument with the inlets sampling directly through the aircraft wall (for full details see Green et al., 2006). The dual-channel inlets directly sampling ambient air avoids two problems previously present in the single-inlet air sample pipe set-up, those of rapidly changing background signal and losses down the air sample pipe.

In an environment with rapidly changing background concentrations, as is the case for aircraft measurements, the background signal changes between two concurrent background cycles and can mask the amplified signal such that determination of the peroxy radical derived signal becomes less accurate. Cantrell et al. (Cantrell et al., 1996) thus developed a dual-channel PERCA where by use of two independent sampling and measurements systems operating out of phase both background and amplified signal are measured simultaneously and constantly. This gives the dual-channel configuration the ability to reduce the influence of atmospheric variability in background signals. Peroxy radical mixing ratios obtained by the dual-channel technique also have

eraging of two background and one amplification period. Dual-channel measurements allow peroxy radical data to be taken on a $1 \mathrm{~Hz}$ timescale, although the data are then averaged to one minute. A more in depth discussion of the advantages of a dualchannel system is described elsewhere (Green et al., 2006).

\section{Peroxy radicals and ozone \\ photochemistry in air masses}

A. E. Parker et al.

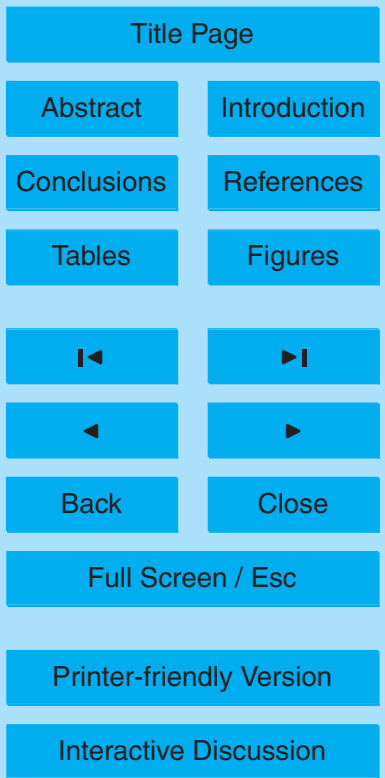




\subsection{Calibration}

Ordinarily the LMA-3 detectors are calibrated by mixing the output from a VICI Metronics $\mathrm{NO}_{2}$ wafer permeation device with varying flows of zero air, but owing to technical problems with the calibration system on-board the BAe-146, it was not possible to 5 perform in-flight calibrations. An alternative method was developed for the BAe-146 by using the background signal on the LMA-3 detectors along with the in-situ ozone measurements made on-board the BAe-146 with a commercial Thermo Environmental Instruments Inc. $49 \mathrm{C}$ ozone analyser. The relative levels of ozone and $\mathrm{NO}_{2}$ encountered during ITOP were such that the background signals measured on the LMA-3 detectors were almost entirely due to the oxidation of reagent NO by ozone with a negligible contribution from ambient $\mathrm{NO}_{2}$. Thus the $\mathrm{NO}_{2}$ sensitivity of the detectors can be calculated for every point of the flight during which ozone measurements are available.

The precision of the ozone calibration method has been evaluated by taking the standard deviation of the ratio of ozone concentration divided by the background signal as a percentage of the mean of the same for a series of straight and level runs within a flight. The precision was determined to be around 6\%.

It was also not possible to perform in-flight chain length calibrations, and consequently calibrations were performed on the ground only. It would be ideal to perform chain length calibrations at different altitudes, as the chain chemistry reactions in the inlets have temperature and pressure dependent rate constants. However, a series of in-flight calibrations were performed by (Green et al., 2003), where no clear chain length dependence on altitude was seen. All reported chain lengths were within error for chain length calculation from the chain length calibrations carried out on the ground. As such, although inflight chain length calibrations would be ideal, to a reasonable approximation using ground calibrations is acceptable.

\section{Peroxy radicals and ozone \\ photochemistry in air masses}

A. E. Parker et al.

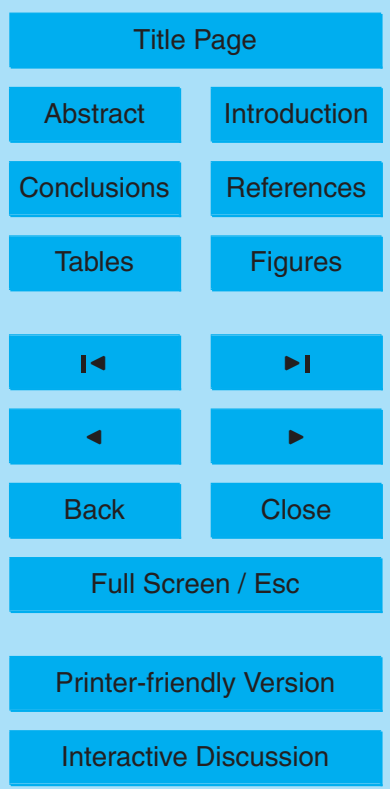




\section{Results}

\subsection{Radicals and tracers}

The average altitude profile of peroxy radicals measured during ITOP is shown in Fig. 1a, the data being binned into $500 \mathrm{~m}$ intervals. The full data set is also shown, 5 coloured by ozone mixing ratio in parts per billion by volume. Figure $1 \mathrm{~b}$ shows the temporal profile of median peroxy radicals over all altitudes. The campaign data set for other important species for the analysis in this paper (such as ozone and NO) can be found in the ITOP overview paper (Lewis et al., 2006). It should be noted that this groups together data from different latitudes and times of day, and thus one bin may be 10 influenced heavily by a single air mass as will be discussed later.

The overall peroxy radical distribution increases with altitude from an average of $28 \mathrm{pptv}$ at $0-0.5 \mathrm{~km}$ to $44 \mathrm{pptv}$ at $5-5.5 \mathrm{~km}$. There are very few points over $5.5 \mathrm{~km}$ owing to the inability of the installed pumping system to maintain a constant flow through the inlets at the lower ambient pressures found at higher attitudes and thus points over $155.5 \mathrm{~km}$ are not considered. Ordinarily the sample flow through the inlets is maintained at a constant rate for all altitudes. Any points where the flow rate is not constant have been removed.

Previous aircraft campaigns that have measured peroxy radicals in the lower/mid troposphere have focussed on the Pacific (e.g. Transport and Chemical Evolution over 20 the Pacific (TRACE-P) campaign - Cantrell et al., 2003b) or over the United States (e.g. Tropospheric Ozone Production about the Spring Equinox (TOPSE) campaign Cantrell et al., 2003a) with some of the earliest measurements over Europe (Reiner et al., 1997). Previous Atlantic campaigns have concentrated on the upper troposphere (e.g. Subsonic Assessment Ozone and Nitrogen Oxide Experiment (SONEX) - Jae25 gle et al., 2000), as opposed to the lower altitudes probed in this study. (Cantrell et al., 2003b) reported that measured values of $\mathrm{HO}_{2}+\Sigma_{i} \mathrm{R}_{i} \mathrm{O}_{2}$ during TRACE-P showed a small peroxy radical maximum at $2-5 \mathrm{~km}$. A slight increase with altitude was also seen during TOPSE (Cantrell et al., 2003a). During ITOP an increase with altitude is

\section{Peroxy radicals and ozone \\ photochemistry in air masses}

A. E. Parker et al.

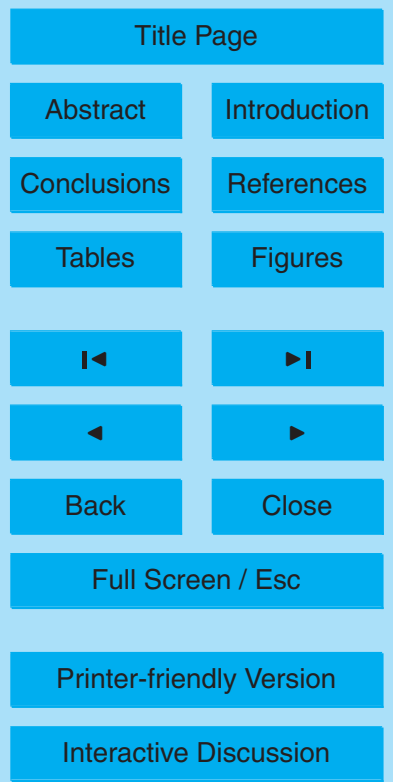


seen to a maximum at $3-5.5 \mathrm{~km}$. However, it is important to note that as the objective of ITOP was to intercept polluted air masses and most of these interceptions happened out of the boundary layer, the profile presented here for all flights is not necessarily that of the background mid-Atlantic. In order to distinguish the background Atlantic, a basic 5 classification of air masses has been performed. Air masses have been divided into three groups comprising marine background air, air of Alaskan fire plume origin and all others, defined by ozone and carbon monoxide mixing ratios. Air with ozone and carbon monoxide mixing ratios of less than 40 ppbv and 90 ppbv respectively is designated marine, and air with a carbon monoxide mixing ratio of greater than $250 \mathrm{ppbv}$ is 10 designated of Alaskan fire plume origin. The levels of peroxy radical conditions found in differing air masses during ITOP are detailed in Table 1. Air characterised with a clean marine origin had a median peroxy radical mixing ratio of 16 pptv and an average mixing ratio of 19 pptv - less than half that of non-marine air. Figure 2 shows the altitude profile of marine background peroxy radicals, from which it can be seen that there is 15 no discernable altitude trend.

An apparent anomaly in the altitude profile of peroxy radicals in marine air shows a distinct peak at $3.5-4 \mathrm{~km}$. The air sampled at this altitude was almost exclusively from flight B036 on 29 July 2004. Flexpart (Stohl et al., 2005) emission tracers for the section of interest of flight B036 show very low concentrations of aged American emissions, and back trajectories (Methven et al., 2006) show air of Atlantic background as shown in Fig. 3.

The air masses classified as Alaskan fire plume origin show no increase in peroxy radicals over standard air masses but a minor decrease in both mean and median of 41 pptv to 36 pptv and 42 pptv to 37 pptv respectively. However, there are only 35 data points available for Alaskan fire plume air masses as the majority of the air masses associated with Alaskan fire plumes encountered were at high altitude where the PERCA had difficulty sampling as noted previously and it is therefore difficult to draw concrete conclusions. However, the fact that peroxy radicals were not elevated in Alaskan fire plume air-masses over the levels found in other non-marine air-masses whilst the me-

\section{Peroxy radicals and ozone \\ photochemistry in air masses}

A. E. Parker et al.

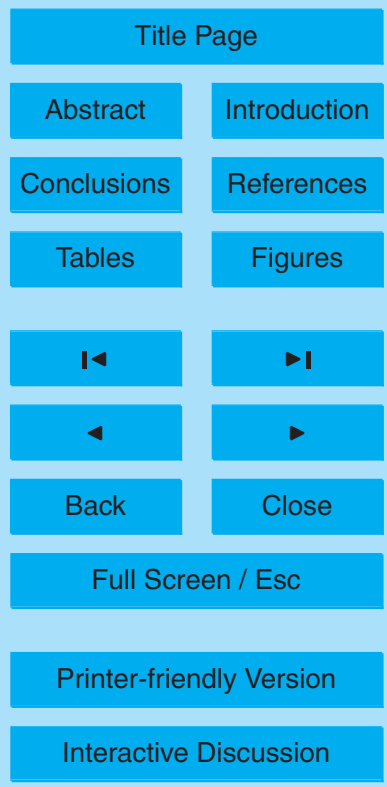


dian concentrations of other species were greatly enhanced, e.g. median NO concentrations were enhanced by over a factor of 5 , and median PAN concentrations were enhanced by more than a factor of 8 , is of interest. Furthermore, within the Alaskan fire plume, airmasses with extremely high $\mathrm{CO}$ mixing ratios of up to $600 \mathrm{ppbv}$ were 5 observed with no associated enhancement of ozone. The non-enhancement of peroxy radicals within Alaskan fire plume air-masses is likely a result of the lack of enhanced ozone, combined with the low temperatures at high altitudes resulting in much $\mathrm{NO}_{2}$ being sequestered into PAN or other reservoir species.

A range of volatile organic compounds (VOCs) were also measured on the BAe10 146. Compounds up to four carbon atoms as detailed in Table 2 have been used to calculate $\mathrm{VOC}$ reactivity as $\Sigma_{i} k_{i}[\mathrm{VOC}]_{i}$ where $k_{i}$ is the rate of reaction of the relevant VOC with $\mathrm{OH}$. Methane was not measured on board the BAe-146 and has been set to a constant 1750 ppbv (Dlugokencky et al., 2003). CO and methane make a significant contribution as is expected, however the additional importance of non-methane 15 hydrocarbons can be seen from Fig. 4. The decrease in $\mathrm{OH}$ reactivity attributed to methane with altitude even though the mixing ratio of methane is set to $1750 \mathrm{ppbv}$ is due to the temperature dependence of the $\mathrm{OH}+\mathrm{CH}_{4}$ rate constant. The combined non-methane hydrocarbons contribute more to $\mathrm{OH}$ reactivity than methane and carbon monoxide combined, and are especially important under $3.5 \mathrm{~km}$. From the measured 20 non-methane hydrocarbons, it is the oxygenated VOCs that make the main contribution to $\mathrm{OH}$ loss as indicated in Fig. 5, with the most significant of those being formaldehyde and acetaldehyde. Indeed, acetaldehyde alone is responsible for almost as much $\mathrm{OH}$ reactivity as carbon monoxide and methane together. However, recent studies have demonstrated that acetaldehyde artefacts may be present in measured data leading 25 to erroneously high concentrations of acetaldehyde being reported (Apel et al., 2003; Northway et al., 2004). It is worth noting that the artefact reported (Apel et al., 2003; Northway et al., 2004) is correlated with ozone, but acetaldehyde data measured during ITOP does not correlate with ozone. Furthermore, the veracity of the acetaldehyde data can be checked by comparing the concentration of peroxyacetyl radicals produced

\section{Peroxy radicals and ozone \\ photochemistry in air masses}

A. E. Parker et al.

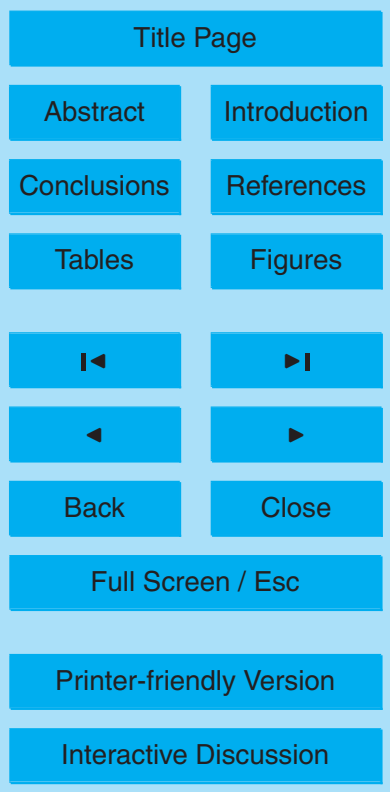

\section{3}


from reaction of $\mathrm{OH}$ with acetaldehyde to that produced from PAN thermal decomposition. Figure 6 shows that at altitudes up to approximately $5 \mathrm{~km}$, there is no clear bias in production of peroxyacetyl radicals. Over approximately $5 \mathrm{~km}$, the production from acetaldehyde oxidation begins to heavily outweigh that from PAN thermolysis. Conse5 quently therefore, whilst acetaldehyde measurements should be treated with caution, it serves to illustrate the potential importance of oxygenated VOCs.

A steady state analysis of the production and loss of peroxy radicals during ITOP has been carried out using the method described by Mihele and Hastie (Mihele and Hastie, 2003). In this analysis it is assumed that peroxy radicals are in steady state, 10 thus

$$
\frac{\mathrm{d}\left[\mathrm{HO}_{2}+\Sigma_{i} \mathrm{R}_{i} \mathrm{O}_{2}\right]}{\mathrm{d} t}=\mathrm{P}_{\left[\mathrm{HO}_{2}+\Sigma_{i} \mathrm{R}_{i} \mathrm{O}_{2}\right]}-\mathrm{L}_{\mathrm{SR}}-\mathrm{L}_{\mathrm{NO}_{\mathrm{x}}}=0
$$

where $\mathrm{P}_{\left[\mathrm{HO}_{2}+\Sigma_{i} \mathrm{R}_{i} \mathrm{O}_{2}\right]}$ is the rate of production of radicals, $\mathrm{L}_{\mathrm{SR}}$ is the rate of loss of peroxy radicals owing to self-reaction, and $\mathrm{L}_{\mathrm{NO}}$ is the rate of loss of peroxy radicals owing to reaction with $\mathrm{NO}_{\mathrm{x}}$. Assuming the major radical source is ozone photolysis and introducing $\gamma$ as an additional fractional radical production, the radical production term becomes:

$$
\mathrm{P}_{\left[\mathrm{HO}_{2}+\Sigma_{i} \mathrm{R}_{i} \mathrm{O}_{2}\right]}=2 f . j\left(\mathrm{O}^{1} \mathrm{D}\right) \cdot\left[\mathrm{O}_{3}\right] \cdot(1+\gamma)
$$

Combining self-reaction rates of $\mathrm{HO}_{2}$ and $\Sigma_{i} \mathrm{R}_{i} \mathrm{O}_{2}$ into a single rate constant $k_{\text {self }}$, setting $\beta=\mathrm{L}_{\mathrm{NO}_{\mathrm{x}}} / \mathrm{L}_{\mathrm{SR}}$ so as to describe the dominant loss mechanism and introducing parameter $\alpha$ to describe the partitioning between $\mathrm{HO}_{2}$ and $\mathrm{RO}_{2}$, thus:

$\alpha=\frac{\left[\mathrm{HO}_{2}\right]}{\left[\mathrm{HO}_{2}+\Sigma_{i} \mathrm{R}_{i} \mathrm{O}_{2}\right]}$

gives the radical loss terms as:

$\mathrm{L}_{\left[\mathrm{HO}_{2}+\Sigma_{i} \mathrm{R}_{i} \mathrm{O}_{2}\right]}=2 \cdot k_{\text {self }} \cdot \alpha(1+\beta) \cdot\left[\mathrm{HO}_{2}+\Sigma_{i} \mathrm{R}_{i} \mathrm{O}_{2}\right]^{2}$

\section{Peroxy radicals and ozone}

photochemistry in air masses
A. E. Parker et al.

\section{Title Page}

Abstract Introduction

Conclusions

References

Tables

Figures

14

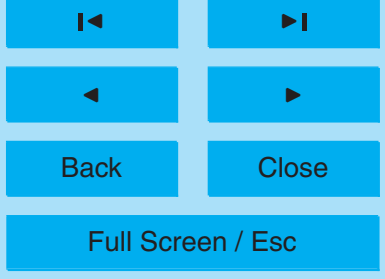

Printer-friendly Version

Interactive Discussion 
where the loss due to self-reaction is given by the following equations,

$$
\begin{aligned}
& \mathrm{HO}_{2}+\mathrm{HO}_{2} \rightarrow \mathrm{H}_{2} \mathrm{O}_{2}+\mathrm{O}_{2} \\
& \mathrm{HO}_{2}+\mathrm{RO}_{2} \rightarrow \mathrm{ROOH}+\mathrm{O}_{2} \\
& \mathrm{RO}_{2}+\mathrm{RO}_{2} \rightarrow \mathrm{ROOR}+\mathrm{O}_{2}
\end{aligned}
$$

5 which leads to the following self-reaction loss rate,

$$
\mathrm{L}_{\mathrm{SR}}=2 k_{8}\left[\mathrm{HO}_{2}\right]\left[\mathrm{HO}_{2}\right]+2 k_{9}\left[\mathrm{HO}_{2}\right]\left[\mathrm{RO}_{2}\right]+2 k_{10}\left[\mathrm{RO}_{2}\right]\left[\mathrm{RO}_{2}\right]
$$

Assuming that $k_{8} \approx k_{9}$, and that $k_{10}$ is slow enough that Reaction (10) can be discarded, Eq. (D) reduces to that found in Mihele and Hastie (Mihele and Hastie, 2003):

$$
\mathrm{L}_{\mathrm{SR}}=2 \cdot k_{\text {self }} \cdot \alpha \cdot\left[\mathrm{HO}_{2}+\Sigma_{i} \mathrm{R}_{i} \mathrm{O}_{2}\right]^{2}
$$

10 However, the assumption in the derivation of the self-reaction loss rate that $k_{8} \approx k_{9}$ only holds if $\mathrm{RO}_{2}$ is solely in the form of $\mathrm{CH}_{3} \mathrm{O}_{2}$, neglecting the contribution of other species. The $\mathrm{OH}$ reactivity calculations earlier in this work have demonstrated that this assumption does not hold for the conditions encountered during ITOP where nonmethane hydrocarbons and especially acetaldehyde are very important in terms of $\mathrm{OH}$ 15 reactivity.

If the acetylperoxy radical is introduced along with the ratio of $\delta=\left[\mathrm{CH}_{3} \mathrm{C}(\mathrm{O}) \mathrm{O}_{2}\right] /\left(\left[\mathrm{CH}_{3} \mathrm{O}_{2}\right]+\left[\mathrm{CH}_{3} \mathrm{C}(\mathrm{O}) \mathrm{O}_{2}\right]\right)$, then the self-reaction loss rate reduces thus:

$\mathrm{L}_{\mathrm{SR}}=$

$2 \cdot\left(\begin{array}{l}k_{8} \alpha^{2}+k_{11} \alpha(1-\alpha)(1-\delta)+k_{12}(1-\alpha)^{2}(1-\delta)^{2}+ \\ k_{13} \alpha(1-\alpha) \delta+k_{14}(1-\alpha)^{2} \delta(1-\delta)+k_{15}(1-\alpha)^{2} \delta^{2}\end{array}\right) \cdot\left[\mathrm{HO}_{2}+\Sigma_{i} \mathrm{R}_{i} \mathrm{O}_{2}\right]^{2}$

where

$$
\mathrm{HO}_{2}+\mathrm{CH}_{3} \mathrm{O}_{2} \rightarrow \text { products }
$$

\section{9, 18793-18838, 2009}

\section{Peroxy radicals and ozone}

photochemistry in air masses

A. E. Parker et al.

\section{Title Page}

Abstract

Conclusions

Tables

14

\section{4}

Back

Full Screen / Esc

Printer-friendly Version

Interactive Discussion 
$\mathrm{CH}_{3} \mathrm{O}_{2}+\mathrm{CH}_{3} \mathrm{O}_{2} \rightarrow$ products

$\mathrm{HO}_{2}+\mathrm{CH}_{3} \mathrm{C}(\mathrm{O}) \mathrm{O}_{2} \rightarrow$ products

$\mathrm{CH}_{3} \mathrm{O}_{2}+\mathrm{CH}_{3} \mathrm{C}(\mathrm{O}) \mathrm{O}_{2} \rightarrow$ products

$\mathrm{CH}_{3} \mathrm{C}(\mathrm{O}) \mathrm{O}_{2}+\mathrm{CH}_{3} \mathrm{C}(\mathrm{O}) \mathrm{O}_{2} \rightarrow$ products

5 If $\delta$ is set to 0.5 , that is half of the $\mathrm{RO}_{2}$ present is in the form of acetylperoxy (the remaining half being $\mathrm{CH}_{3} \mathrm{O}_{2}$ ), then at $298 \mathrm{~K}$, the combined peroxy radical self-reaction rate is approximately double the self-reaction rate when $\delta$ is zero. Further to this, the rate constant for the reaction of acetylperoxy with $\mathrm{NO}$ is approximately 2.6 times faster than that for methylperoxy with $\mathrm{NO}$ at $298 \mathrm{~K}$. Consequently, the loss rate of peroxy 10 radicals through reaction with $\mathrm{NO}_{x}$ will also be greater than if all the $\mathrm{RO}_{2}$ were $\mathrm{CH}_{3} \mathrm{O}_{2}$. The importance of this relative to $\beta$ and $\gamma$ shall be shown in the following section.

Assuming that all $\mathrm{RO}_{2}$ is in the form of $\mathrm{CH}_{3} \mathrm{O}_{2}$, the peroxy radical steady state can thus be re-written as

$\frac{\mathrm{d}\left[\mathrm{HO}_{2}+\Sigma_{i} \mathrm{R}_{i} \mathrm{O}_{2}\right]}{\mathrm{dt}}=2 f \cdot j\left(\mathrm{O}^{1} \mathrm{D}\right) \cdot\left[\mathrm{O}_{3}\right] \cdot(1+\gamma)-2 \cdot k_{\text {self }} \cdot \alpha(1+\beta) \cdot\left[\mathrm{HO}_{2}+\Sigma_{i} \mathrm{R}_{i} \mathrm{O}_{2}\right]^{2}=0$

15 where $f$ is a measure of the proportion of $O\left({ }^{1} D\right)$ produced that consequently react with water vapour and is given by Eq. $(\mathrm{H})$,

$f=\frac{k_{16}\left[\mathrm{H}_{2} \mathrm{O}\right]}{k_{16}\left[\mathrm{H}_{2} \mathrm{O}\right]+k_{17}[\mathrm{M}]}$

where $k_{16}$ and $k_{17}$ are the reaction rates for Reactions (16) and (17) respectively.

$$
\mathrm{O}\left({ }^{1} \mathrm{D}\right)+\mathrm{H}_{2} \mathrm{O} \rightarrow \mathrm{OH}+\mathrm{OH}
$$

$$
\mathrm{O}\left({ }^{1} \mathrm{D}\right)+\mathrm{M} \rightarrow \mathrm{O}\left({ }^{3} \mathrm{P}\right)+\mathrm{M}
$$

The term $j\left(O^{1} \mathrm{D}\right)$ is the photolysis rate of ozone to produce excited oxygen atoms (Reaction 18), and here is modelled data from the Tropospheric Ultraviolet and Visible radiation model (TUV) version 4 (Madronich and Flocke, 1998). Filter radiometers

\section{Peroxy radicals and} ozone

photochemistry in air masses

A. E. Parker et al.

\section{Title Page}

Abstract

Introduction

Conclusions

Tables

References

Figures

14

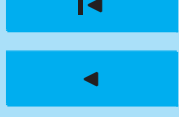

Back

Close

Printer-friendly Version

Interactive Discussion 
(Phillips, 2002; Volz-Thomas et al., 1996; Junkerman et al., 1989) to measure $j\left(O^{1} D\right)$ and $j\left(\mathrm{NO}_{2}\right)$ (the photolysis rate of Reaction 21) were fitted to the aircraft during ITOP, but unfortunately owing to technical problems with the data logging the data produced was unusable. Consequently, all photolysis frequencies should be considered clear

5 sky maxima. The impact of this is dependent on whether measurements were being made above or below clouds.

$$
\mathrm{O}_{3}+h v \rightarrow \mathrm{O}_{2}+\mathrm{O}\left({ }^{1} \mathrm{D}\right)
$$

Equation $(G)$ can be rearranged to give the following expression for peroxy radical concentrations,

${ }_{10}\left[\mathrm{HO}_{2}+\Sigma_{i} \mathrm{R}_{i} \mathrm{O}_{2}\right] \approx \sqrt{\frac{2 f \cdot j\left(\mathrm{O}^{1} D\right) \cdot\left[\mathrm{O}_{3}\right] \cdot(1+\gamma)}{2 \cdot k_{\text {self }} \cdot \alpha(1+\beta)}}=\sqrt{\frac{f \cdot j\left(\mathrm{O}^{1} D\right) \cdot\left[\mathrm{O}_{3}\right]}{k_{\text {self }}}} \sqrt{\frac{1}{\alpha}} \sqrt{\frac{1}{1+\beta}} \sqrt{1+\gamma}$

$\beta$ is therefore a measure of the dominant loss process for peroxy radicals. If $\beta$ is less than one, then the dominant loss process is radical self-reaction rather than loss through reaction with $\mathrm{NO}_{\mathrm{x}}$. Figure 7 is a time series of $\beta$ for flights $\mathrm{B} 031$ to B034 and B036 to B039. B029 and B030 are omitted owing to a lack of NO data, and B035 15 because of a lack of PAN data. For the time series as a whole, $\beta$ is greater than one for just over $35 \%$ of points, demonstrating that even in the low $\mathrm{NO}_{\mathrm{x}}$ conditions encountered during ITOP the loss of peroxy radicals owing to reaction with $\mathrm{NO}_{\mathrm{x}}$ is important. If acetylperoxy is considered in addition to methylperoxy with $\delta=0.5$, then $\beta$ is greater than one for just over $26 \%$ of points whilst the median value for $\beta$ drops 20 from 0.62 to 0.40 , showing that whilst the peroxy radical self-reaction accounts for more peroxy radical loss, reaction with $\mathrm{NO}_{x}$ remains at an appreciable level. The continued relevance of reaction with $\mathrm{NO}_{x}$ is as the combined rate constant for $\left[\mathrm{HO}_{2}+\Sigma_{i} \mathrm{R}_{i} \mathrm{O}_{2}\right]+\mathrm{NO}$ is of a similar value to that for the peroxy radical self-reaction rate constant. Thus only low concentrations of $\mathrm{NO}_{\mathrm{x}}$ are needed for peroxy radical losses due to reaction with $\mathrm{NO}_{x}$ to become significant.

\section{Peroxy radicals and ozone \\ photochemistry in air masses}

A. E. Parker et al.

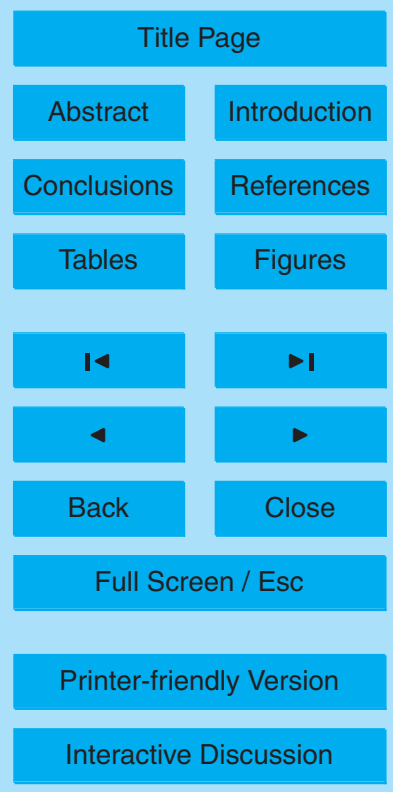

18807 
$\gamma$ is a measure of additional peroxy radical production from sources other than ozone photolysis. Therefore a $\gamma$ of zero indicates no excess production, whilst a $\gamma$ of less than zero indicates that a higher concentration of peroxy radicals is calculated from ozone photolysis than is actually observed. Setting $\alpha$ equal to 0.5 (as $\mathrm{HO}_{2}$ and $\Sigma_{i} \mathrm{R}_{i} \mathrm{O}_{2}$ were 5 not measured discretely during ITOP) and $\delta$ equal to 0 , and rearranging Eq. (I) results in an expression for gamma as per Mihele and Hastie (Mihele and Hastie, 2003), thus,

$\gamma=\left(\left[\mathrm{HO}_{2}+\Sigma_{i} \mathrm{R}_{i} \mathrm{O}_{2}\right]^{2} \cdot \alpha \cdot(1+\beta) \cdot \frac{k_{\text {self }}}{f . j\left(\mathrm{O}^{1} \mathrm{D}\right) \cdot\left[\mathrm{O}_{3}\right]}\right)-1$

As can be seen from Fig. 8 ( $\gamma+1$ is shown so that the $y$-axis can be logarithmic), $\gamma$ is less than zero for the ITOP time series for some $19 \%$ of points. This low $\gamma$ could be due to either an overestimation of peroxy radical production from ozone photolysis or due to underestimation of peroxy radical losses. There is scope for overestimation of peroxy radical production in this work due to $j\left(O^{1} \mathrm{D}\right)$ being from TUV modelled values rather than measured and thus a clear sky limit. Furthermore, $\gamma$ is negative more often at lower altitudes, which would correspond to higher cloud cover at lower altitudes and 15 thus a greater $j\left(O^{1} D\right)$ overestimation from TUV. There is also scope for an underestimation of peroxy radical losses both from self-reactions and reactions with $\mathrm{NO}_{\mathrm{x}}$ owing to the assumption that all $\mathrm{RO}_{2}$ is present in the form of $\mathrm{CH}_{3} \mathrm{O}_{2}$. If $\delta$ is set to 0.5 such that half of the peroxy radicals present are $\mathrm{CH}_{3} \mathrm{C}(\mathrm{O}) \mathrm{O}_{2}$ and half $\mathrm{CH}_{3} \mathrm{O}_{2}$ and $\mathrm{Eq}$. $(\mathrm{J})$ is rewritten to take account of the expanded peroxy radical loss rates with the addition of 20 acetylperoxy reactions, then $\gamma$ is increased by a large amount over that given by Eq. $(\mathrm{J})$, with the median value for $\gamma$ more than doubling. It should be noted that owing to the possible unreliability of acetaldehyde data, the use herein of acetylperoxy radicals as forming half the concentration of $\sum_{i} \mathrm{R}_{i} \mathrm{O}_{2}$ (with the remaining half being $\mathrm{CH}_{3} \mathrm{O}_{2}$ ) is as a useful proxy for demonstrating the potential importance of fast reacting peroxy 25 radicals.

B032 especially shows very large $\gamma$ values, indicating large amounts of excess radical production over that from ozone photolysis alone. Possible sources of peroxy rad18808
9, 18793-18838, 2009

\section{Peroxy radicals and ozone \\ photochemistry in air masses}

A. E. Parker et al.

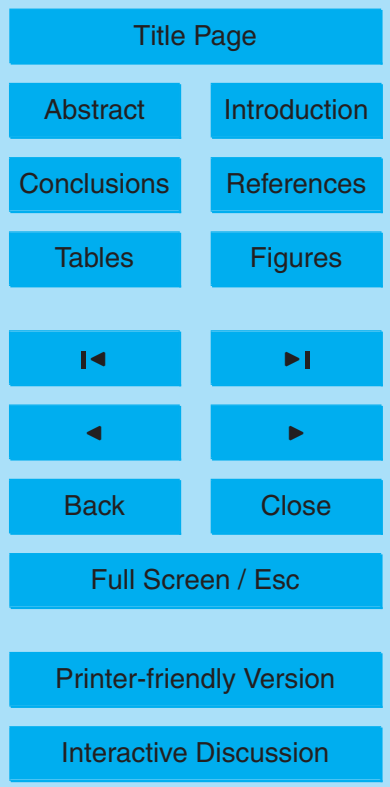


icals apart from ozone photolysis include alkene ozonolysis, PAN decomposition, and photolysis of carbonyls. During flight B032 Alaskan fire plumes were encountered with very high mixing ratios of PAN - the flight mean and median PAN mixing ratios were 1018 pptv and 785 pptv respectively, compared to a campaign mean and median of 5316 pptv and 217 pptv respectively. NO was also enhanced over the campaign average, with the B032 median being 89 pptv compared to 21 pptv for the campaign, and the mean being 88 pptv compared to 36 pptv.

\subsection{Overall photochemistry}

The net photochemical ozone production or loss gives a measure of instantaneous insitu ozone production or loss within an air-mass and has been calculated in this work from measured peroxy radicals, thus,

$\mathrm{N}\left(\mathrm{O}_{3}\right)=k_{\mathrm{c}} \cdot\left[\mathrm{HO}_{2}+\Sigma_{\mathrm{i}} \mathrm{R}_{\mathrm{i}} \mathrm{O}_{2}\right] \cdot[\mathrm{NO}]-\left\{f \cdot j\left(\mathrm{O}^{1} \mathrm{D}\right)+k_{19}[\mathrm{OH}]+k_{20}\left[\mathrm{HO}_{2}\right]\right\}\left[\mathrm{O}_{3}\right]$

with $k_{\mathrm{c}}$ representing the combined rate constant for oxidation of $\mathrm{NO}$ to $\mathrm{NO}_{2}$ by $\Sigma_{i} \mathrm{R}_{i} \mathrm{O}_{2}$ and $\mathrm{HO}_{2}$ (Reactions 1 and 3 ) and $k_{19}$ and $\mathrm{k}_{20}$ the reaction rates for Reactions (19) and 15 (20) respectively.

$$
\begin{aligned}
& \mathrm{OH}+\mathrm{O}_{3} \rightarrow \mathrm{HO}_{2}+\mathrm{O}_{2} \\
& \mathrm{HO}_{2}+\mathrm{O}_{3} \rightarrow \mathrm{OH}+2 \mathrm{O}_{2}
\end{aligned}
$$

The first term in Eq. (K) is the ozone production term and is the only known way of producing ozone in the troposphere in excess of the photostationary steady state between ozone and $\mathrm{NO}_{\mathrm{x}}$. $\mathrm{NO}_{2}$ produced from the oxidation of $\mathrm{NO}$ by peroxy radicals in Reactions (1) and (3) is photolysed to produce oxygen atoms that then form ozone, viz,

$$
\begin{aligned}
& \mathrm{NO}_{2}+h v \rightarrow \mathrm{NO}+\mathrm{O}\left({ }^{3} \mathrm{P}\right) \\
& \mathrm{O}\left({ }^{3} \mathrm{P}\right)+\mathrm{O}_{2}+\mathrm{M} \rightarrow \mathrm{O}_{3}+\mathrm{M}
\end{aligned}
$$

\section{ACPD}

9, 18793-18838, 2009

\section{Peroxy radicals and ozone}

photochemistry in air masses
A. E. Parker et al.

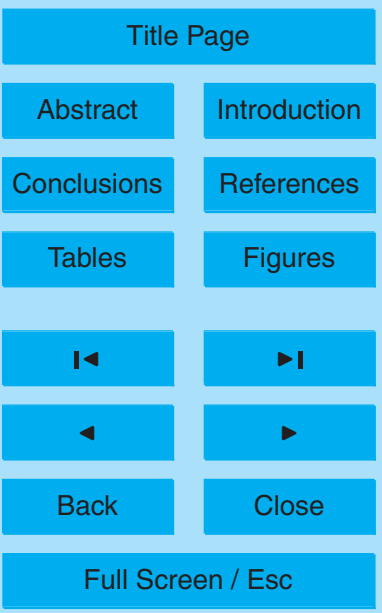

Printer-friendly Version

Interactive Discussion 
The other terms of Eq. $(\mathrm{K})$ represent the loss processes of ozone in the troposphere, specifically the photolysis of ozone to form excited ozone atoms multiplied by $f$, the proportion of $\mathrm{O}\left({ }^{1} \mathrm{D}\right)$ that then react with water vapour, the reaction of ozone with $\mathrm{OH}$ (Reaction 19), and the reaction of ozone with $\mathrm{HO}_{2}$ (Reaction 20). As stated previously, 5 photolysis rates used in this paper are modelled values, and thus ozone loss rates should be considered clear sky maxima.

The net ozone production or loss rate calculated by Eq. $(\mathrm{K})$ contains a number of assumptions such as neglecting cloud processes, dry deposition, and reactions with alkenes and halogens. Nevertheless, Eq. (K) remains a good approximation for the 10 free troposphere.

$\mathrm{OH}$ and $\mathrm{HO}_{2}$ were not measured discretely during ITOP, and so assumptions have to be made about their concentrations. In this work $\alpha$ has been taken as 0.5 and the concentration of $\mathrm{OH}$ radicals has been taken at $1 \times 10^{6}$ molecules $\mathrm{cm}^{-3}$. A sensitivity analysis with $\mathrm{OH}$ concentrations of $1 \times 10^{6}$ molecules $\mathrm{cm}^{-3}$ and $5 \times 10^{6}$ molecule $\mathrm{cm}^{-3}$ corresponding to a reasonable minimum and 90th percentile value respectively as derived from $\mathrm{OH}$ data recorded between ground level and $7 \mathrm{~km}$ on the NASA DC-8 during INTEX-NA demonstrated that the ozone loss term is relatively insensitive to $\mathrm{OH}$ concentration as increasing the $\mathrm{OH}$ concentration from $1 \times 10^{6}$ molecules cm $\mathrm{cm}^{-3}$ to $5 \times 10^{6}$ molecules $\mathrm{cm}^{-3}$ results in an increase of average $\mathrm{L}^{\mathrm{CS}}\left(\mathrm{O}_{3}\right)$ of $0.04 \mathrm{ppbv} \mathrm{h}^{-1}$ from $20 \quad 0.51 \mathrm{ppbv} \mathrm{h}^{-1}$ to $0.55 \mathrm{ppbv} \mathrm{h}^{-1}$.

Photochemical activity as characterised by enhanced peroxy radicals was observed within long-range transport air-masses with young east-coast North American air masses, biomass burning, and aged Asian emission signatures. Enhanced peroxy radicals (and photochemical ozone production) were also seen within low-level transported air masses, a larger than normal number of which occurred during the summer of 2004. A specific example of a low-level export event is presented later in this paper. A time series of $\mathrm{P}\left(\mathrm{O}_{3}\right), \mathrm{L}^{\mathrm{CS}}\left(\mathrm{O}_{3}\right)$ and $\mathrm{N}\left(\mathrm{O}_{3}\right)$ for all flights is shown in Fig. 9. Figure 10a, $b$ and $c$ show binned altitude profiles for $\mathrm{P}\left(\mathrm{O}_{3}\right), \mathrm{L}^{\mathrm{CS}}\left(\mathrm{O}_{3}\right)$ and $\mathrm{N}\left(\mathrm{O}_{3}\right)$ respectively, Fig. 10d shows median $\mathrm{P}\left(\mathrm{O}_{3}\right), \mathrm{L}^{\mathrm{CS}}\left(\mathrm{O}_{3}\right)$ and $\mathrm{N}\left(\mathrm{O}_{3}\right)$ split into $30 \mathrm{~min}$ time bins, with

\section{Peroxy radicals and ozone \\ photochemistry in air masses}

A. E. Parker et al.

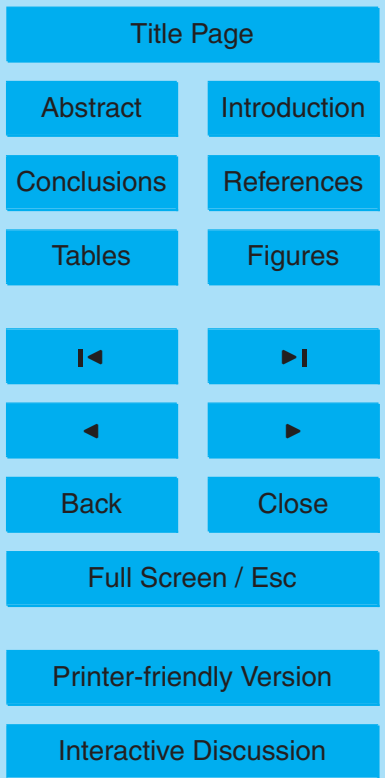

18810 
$\mathrm{N}\left(\mathrm{O}_{3}\right)$ shown for $\alpha=0.25,0.5$ and 0.75 . Table 3 shows net ozone production in different air masses defined as for peroxy radicals previously. It is interesting to note that the air designated of marine background has a net ozone loss rate of almost twice that of the remainder of the air. The same proviso is true for Alaskan Fire plume designated air 5 masses with $\mathrm{N}\left(\mathrm{O}_{3}\right)$ as previously with $\left[\mathrm{HO}_{2}+\Sigma_{i} \mathrm{R}_{i} \mathrm{O}_{2}\right]$; as there are only 30 points available for the entire campaign, it is not possible to draw any conclusions about conditions in these air masses.

In general, the summertime mid-latitude Atlantic is net ozone destructive at clear sky limit. This is true of air classified as both marine background air and non-marine 10 background air. There were however many individual long-range transport events that showed enhanced ozone production, an example of one of which is presented later as a case study. A peak in overall net ozone production can be seen in the altitude profile within the $5-5.5 \mathrm{~km}$ band. This increase is driven by an increase in ozone production rate, rather than a reduction in loss rate. This altitude band is biased towards a single flight that is $48 \%$ of points are from flight B032 on 20 July 2004 and of the points with positive $\mathrm{N}\left(\mathrm{O}_{3}\right)$, over $70 \%$ are from $\mathrm{B} 032$. During flight $\mathrm{B} 032$ long periods of biomass burning influenced air masses were encountered, with air masses characterised by high CO mixing ratios of consistently above 100 ppbv with peaks over 400 ppbv, enhanced NO mixing ratios with the median value being $88.7 \mathrm{pptv}$ compared to $20.8 \mathrm{pptv}$ campaign average, and enhanced PAN mixing ratios with a flight median of $785 \mathrm{pptv}$ as opposed to the campaign median of $217 \mathrm{pptv}$. In contrast the median peroxy radical mixing ratio for flight B032 was $36.6 \mathrm{pptv}$ compared to the campaign median of 34.4 pptv. The large enhancement in $\mathrm{P}\left(\mathrm{O}_{3}\right)$ for flight $\mathrm{B} 032$ is thus driven by NO rather than peroxy radicals.

25 The $P\left(\mathrm{O}_{3}\right)$ being driven by $\mathrm{NO}$ is consistent for the campaign as a whole. Ozone production rate and NO are well correlated $\left(r^{2}=0.72\right)$ as shown in Fig. 11, and thus ozone production for the summer mid-Atlantic may be said to be $\mathrm{NO}_{x}$ limited.

Peroxy radicals and ozone

photochemistry in air masses

A. E. Parker et al.

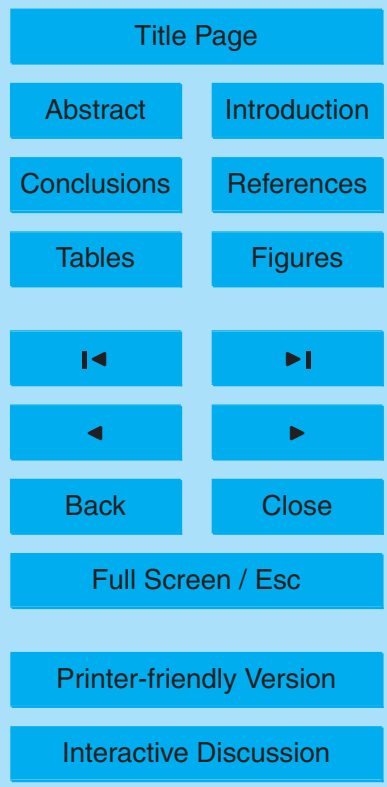




\section{Case studies}

\subsection{Low level $(4.5 \mathrm{~km})$ long-range transport}

Flight B029 on 15 July 2004 presented a good opportunity to sample American outflow. In the period 14:45 to 15:05 LT a prolonged period of moderately to well aged air of

5 American and Asian outflow was encountered with a biomass burning $\mathrm{CO}$ signature as shown by Flexpart analyses. The air mass was transported at low level, staying under $4.5 \mathrm{~km}$ for the majority of the time, as shown by back trajectories. The period 14:45 to 15:05 LT during flight B029 sees peroxy radicals of 30-40 pptv with higher peaks and enhanced ozone in addition to carbon monoxide as shown in Fig. 12. The

10 Flexpart trajectories in Fig. 13a indicate air of mainly North American origin. However, the period directly following between 15:10 and 15:25 LT shows very low peroxy radical mixing ratios on the order of $5-10$ pptv. Ozone is also at significantly lower mixing ratios during this period at $15-25 \mathrm{ppbv}$ compared to the $70-80 \mathrm{ppbv}$ of the preceding period. The Flexpart trajectories for this period in Fig. 13b show air of Atlantic origin. This enhancement of peroxy radicals in an American origin air-mass is just one example of enhanced photochemical activity within low-level transport experienced during ITOP, a hitherto little characterised form of long-range transport. However, some case studies of low level export events seen over the Azores in July 2003 are presented in Owen et al. (Owen et al., 2006). A lack of NO measurements means that it is unfortunately not possible to calculate ozone production rates for this flight.

\subsection{Multiple Interceptions of American Export}

Some flights allowed the opportunity to intercept long-range transported air-masses on multiple occasions. One such opportunity occurred on 31 July 2004 during flight B037. During this flight a prolonged period of US emissions of moderate age were encountered, as shown by Flexpart products. From the time series of ozone production, clear sky ozone loss and net ozone production in Fig. 14, it can be seen that during the pe-

\section{Peroxy radicals and ozone \\ photochemistry in air masses}

A. E. Parker et al.

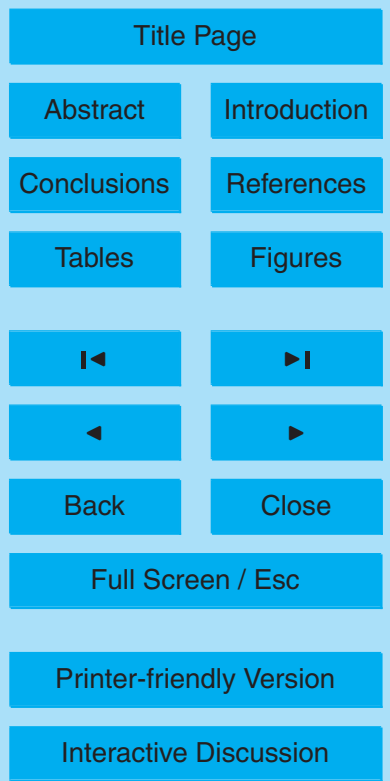


riod 11:00 to 13:20 LT there were multiple interceptions of US export interspersed with a period of Atlantic origin air. The first interception was between the times of approximately 11:00 and 11:30 LT, when a relatively young East Coast funnelled air mass was encountered showing enhanced ozone of up to $90 \mathrm{ppbv}$ and $\mathrm{CO}$ exceeding $110 \mathrm{ppbv}$,

5 peaking at $130 \mathrm{ppbv}$. During this period $\mathrm{N}\left(\mathrm{O}_{3}\right)$ is enhanced to up to $0.5 \mathrm{ppbv} \mathrm{h}^{-1}$ even at clear sky limited $\mathrm{L}^{\mathrm{CS}}\left(\mathrm{O}_{3}\right)$, clearly showing photochemical ozone production within air masses undergoing long-range transport. Another interception was made between $12: 30$ and 13:20 LT again showing strong photochemically active US emissions. Peak $\mathrm{N}\left(\mathrm{O}_{3}\right)$ is over $0.8 \mathrm{ppbv} \mathrm{h}^{-1}$, and is at least net neutral at clear sky limit. These two periods of ozone production are interspersed by a time of Atlantic origin air in which there is net ozone destruction, as demonstrated by the back trajectories in Fig. 15. This is clear evidence for ozone production in long-range transported air masses and indicates the impact that long-range transported air masses can have on regions remote from the source and the consequent implications for local pollution controls. The time 15 period covered here also includes a lagrangian matched air-mass (case 5 in Methven et al. (Methven et al., 2006).

\section{Conclusions}

The sum of peroxy radicals has been measured with the Peroxy Radical Chemical Amplification technique onboard the FAAM BAe Systems 146-300 aircraft during the ITOP 20 campaign in the summer of 2004 over the mid-Atlantic. The overall peroxy radical altitude profile displays an increase with altitude, but as the aim of ITOP was to target polluted air-masses this should not be taken as a summer-time mid-tropospheric midAtlantic background. The peroxy radical altitude profile for air classified as of marine origin (ozone and carbon monoxide mixing ratios of less than $40 \mathrm{ppbv}$ and $90 \mathrm{ppbv}$ 25 respectively) shows no discernable altitude profile. A range of air-masses were intercepted with varying source signatures, including those with aged American and Asian signatures, air-masses of biomass burning origin, and those that originated from the

\section{Peroxy radicals and ozone \\ photochemistry in air masses}

A. E. Parker et al.

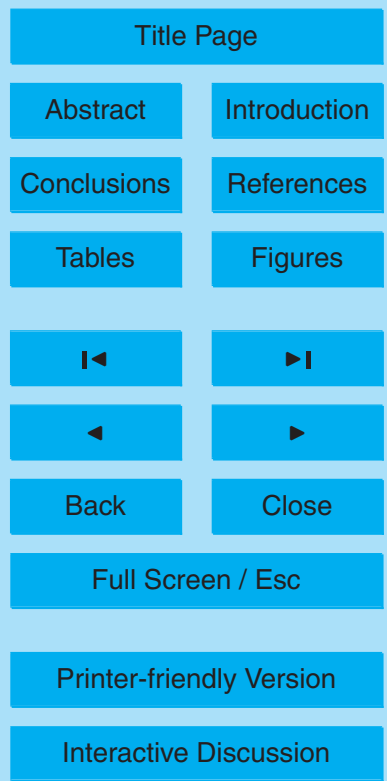


east coast of the United States. Enhanced peroxy radical concentrations have been observed within this range of air-masses indicating that long-range transported airmasses traversing the Atlantic show significant photochemical activity.

VOC reactivity was calculated as $\Sigma_{i} k_{i}[\mathrm{VOC}]_{i}$ where $k_{i}$ is the rate of reaction of the 5 relevant $\mathrm{VOC}$ with $\mathrm{OH}$. The combined non-methane hydrocarbons contribute more to $\mathrm{OH}$ reactivity than methane and carbon monoxide combined, and are especially important under $3.5 \mathrm{~km}$. Of the non-methane hydrocarbons, the oxygenated VOCs make the main contribution to $\mathrm{OH}$ loss, with the most significant of those being formaldehyde and acetaldehyde. Indeed, acetaldehyde alone is responsible for almost as much $10 \mathrm{OH}$ reactivity as carbon monoxide and methane together. However, owing to potential artefacts in the measured acetaldehyde, these data should be treated with some caution. The effect of acetylperoxy radicals on calculated $\beta$ and $\gamma$ values has shown that in environments where the dominant VOC is no longer methane, fast reacting peroxy radicals can have a large effect on any analysis carried out and cannot be ignored.

15 Instantaneous ozone production efficiencies have been calculated for all ITOP flights for which both peroxy radical and NO data are available. The net ozone production at clear sky limit is in general negative, and as such the summer mid-Atlantic troposphere is at limit net ozone destructive. However, there is clear evidence of positive ozone production even at clear sky limit within air masses undergoing long-range transport, and during ITOP especially between 5 and $5.5 \mathrm{~km}$, which in the main corresponds to a flight that extensively sampled air with a biomass burning signature. Ozone production was $\mathrm{NO}_{\mathrm{x}}$ limited throughout ITOP, as evidenced by a good correlation $\left(r^{2}=0.72\right)$ between $\mathrm{P}\left(\mathrm{O}_{3}\right)$ and NO. Strong positive net ozone production has also been seen in varying source signature air-masses undergoing long-range transport, including but not limited to low-level export events, and export from the east coast of the United States.

Acknowledgements. We wish to acknowledge the Natural Environment Research Council for financial support under grant NER/T/S/2002/00578 and for a studentship for A. Parker. The authors would like to thank the University of Leicester Chemistry Electrical and Mechanical workshops, especially P. Acton, G. Butler, K. Wilkinson and R. Batchen for instrument con-

\section{Peroxy radicals and ozone \\ photochemistry in air masses}

A. E. Parker et al.

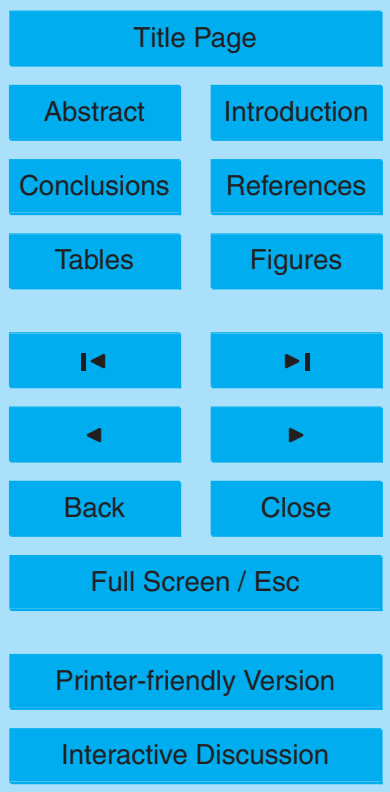


struction, FAAM, Avalon Engineering and Direct Flight Limited for support pre-, during and post- ITOP, and all ITOP contributors for collaboration and data provision. S. Penkett wishes to acknowledge the Leverhulme Trust for the award of a Leverhulme Emeritus Fellowship

\section{References}

5 Apel, E. C., Hills, A. J., Lueb, R., Zindel, S., Eisele, S., and Riemer, D. D.: A fast-GC/MS system to measure $\mathrm{C}_{2}$ to $\mathrm{C}_{4}$ carbonyls and methanol aboard aircraft, J. Geophys. Res., 108(D20), 8794, doi:10.1029/2002JD003199, 2003.

Atkinson, R.: Kinetics and mechanisms of the gas-phase reactions of the hydroxyl radical with organic compounds under atmospheric conditions, Chem. Rev., 86(1), 69-201, 1986.

Atkinson, R.: Kinetics of the gas-phase reactions of $\mathrm{OH}$ radicals with alkanes and cycloalkanes, Atmos. Chem. Phys., 3, 2233-2307, 2003, http://www.atmos-chem-phys.net/3/2233/2003/.

Atkinson, R., Baulch, D. L., Cox, R. A., Crowley, J. N., Hampson Jr, R. F., Hynes, R. G., Jenkin, M. E., Kerr, J. A., Rossi, M. J., and Troe, J.: Summary of Evaluated Kinetic and Photochemical Data for Atmospheric Chemistry, Web Version July, 2004, http://www.iupac-kinetic.ch. cam.ac.uk/summary/IUPACsumm_web_July2004.pdf.

Atkinson, R., Baulch, D. L., Cox, R. A., Crowley, J. N., Hampson Jr, R. F., Hynes, R. G., Jenkin, M. E., Kerr, J. A., Rossi, M. J., and Troe, J.: Summary of Evaluated Kinetic and Photochemical Data for Atmospheric Chemistry, Web Version March, 2005, http://www.iupac-kinetic.ch.cam.ac.uk/summary/IUPACsumm_web_March2005.pdf.

Atkinson, R., Baulch, D. L., Cox, R. A., Crowley, J. N., Hampson Jr, R. F., Hynes, R. G., Jenkin, M. E., Kerr, J. A., Rossi, M. J., and Troe, J.: Summary of Evaluated Kinetic and Photochemical Data for Atmospheric Chemistry, Web Version February, 2006, http://www. iupac-kinetic.ch.cam.ac.uk/summary/IUPACsumm_web_Feb2006.pdf.

Boodaghians, R. B., Hall, I. W., Toby, F. S., and Wayne, R. P.: Absolute determinations of the kinetics and temperature dependences of the reactions of $\mathrm{OH}$ with a series of alkynes, J. Chem. Soc. Faraday T., 2, 83, 1987.

Cantrell, C. A. and Stedman, D. H.: A Possible Technique for the Measurement of Atmospheric Peroxy-Radicals, Geophys. Res. Lett., 9, 846-849, 1982.

Peroxy radicals and ozone

photochemistry in air masses

A. E. Parker et al.

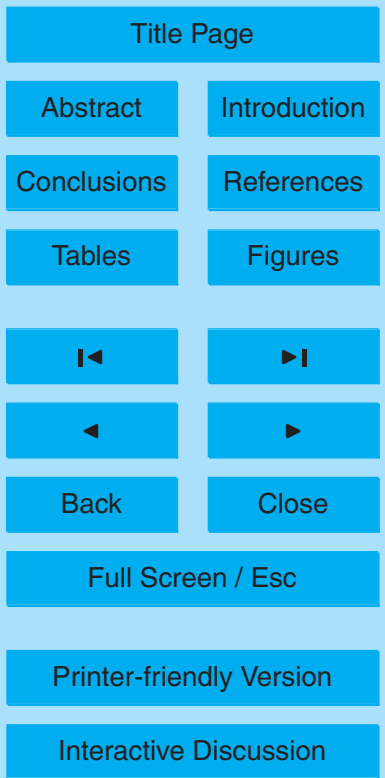

18815 
Cantrell, C. A., Stedman, D. H., and Wendel, G. J.: Measurement of Atmospheric PeroxyRadicals by Chemical Amplification, Anal. Chem., 56, 1496-1502, 1984.

Cantrell, C. A., Shetter, R. E., Calvert, J. G., Parrish, D. D., Fehsenfeld, F. C., Goldan, P. D., Kuster, W., Williams, E. J., Westberg, H. H., Allwine, G., and Martin, R.: Peroxy-Radicals as 5 Measured in Rose and Estimated from Photostationary State Deviations, J. Geophys. Res. Atmos., 98, 18355-18366, 1993.

Cantrell, C. A., Shetter, R. E., and Calvert, J. G.: Dual-inlet chemical amplifier for atmospheric peroxy radical measurements, Anal. Chem., 68, 4194-4199, 1996.

Cantrell, C. A., Edwards, G. D., Stephens, S., Mauldin, L., Kosciuch, E., Zondlo, M., and Eisele, F.: Peroxy radical observations using chemical ionization mass spectrometry during TOPSE, J. Geophys. Res. Atmos., 108(D6), 8371, doi:10.1029/2002JD002715, 2003a.

Cantrell, C. A., Edwards, G. D., Stephens, S., Mauldin, R. L., Zondlo, M. A., Kosciuch, E., Eisele, F. L., Shetter, R. E., Lefer, B. L., Hall, S., Flocke, F., Weinheimer, A., Fried, A., Apel, E., Kondo, Y., Blake, D. R., Blake, N. J., Simpson, I. J., Bandy, A. R., Thornton, D. C., Heikes, B. G., Singh, H. B., Brune, W. H., Harder, H., Martinez, M., Jacob, D. J., Avery, M. A., Barrick, J. D., Sachse, G. W., Olson, J. R., Crawford, J. H., and Clarke, A. D.: Peroxy radical behavior during the Transport and Chemical Evolution over the Pacific (TRACE-P) campaign as measured aboard the NASA P-3B aircraft, J. Geophys. Res. Atmos., 108(D20), 8791, doi:10.1029/2003JD003674, 2003b.

Derwent, R. G., Stevenson, D. S., Collins, W. J., and Johnson, C. E.: Intercontinental transport and the origins of the ozone observed at surface sites in Europe, Atmos. Environ., 38, 18911901, 2004.

Dlugokencky, E. J., Houweling, S., Bruhwiler, L., Masarie, K. A., Lang, P. M., Miller, J. B., and Tans, P. P.: Atmospheric methane levels off: Tempory pause or a new steady-state?, Geophys. Res. Lett., 30(19), 1992, doi:10.1029/2003GL018126, 2003.

Duncan, B. N. and Bey, I.: A modeling study of the export pathways of pollution from Europe: Seasonal and interannual variations (1987-1997), J Geophys. Res. Atmos., 109, D08301, doi:10.1029/2003JD004079, 2004.

Edwards, G. D., Cantrell, C. A., Stephens, S., Hill, B., Goyea, O., Shetter, R. E., Mauldin, R. L., III, Kosciuch, E., Tanner, D. J., and Eisele, F. L.: Chemical Ionization Mass Spectrometer Instrument for the Measurement of Tropospheric $\mathrm{HO}_{2}$ and $\mathrm{RO}_{2}$, Anal. Chem., 75, 53175327, 2003.

Fehsenfeld, F. C., Trainer, M., Parrish, D. D., Volz-Thomas, A., and Penkett, S. A.: North At-

\section{Peroxy radicals and ozone \\ photochemistry in air masses}

A. E. Parker et al.

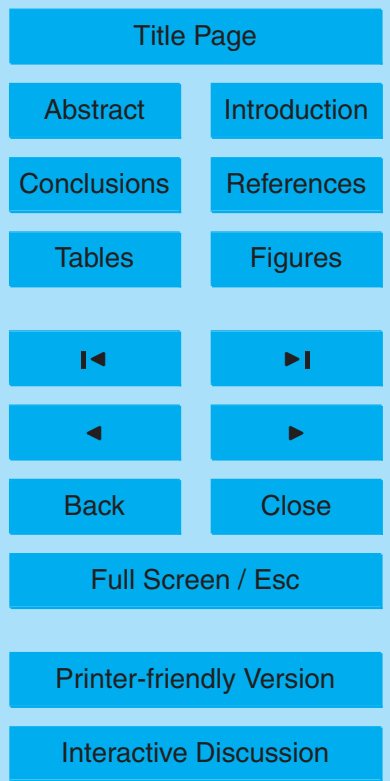


lantic Regional Experiment 1993 summer intensive: Foreword, J. Geoph. Res. Atmos., 101, 28 869-28 875, 1996.

Fehsenfeld, F. C., Ancellet, G., Bates, T. S., Goldstein, A. H., Hardesty, R. M., Honrath, R., Law, K. S., Lewis, A. C., Leatich, R., McKeen, S., Meagher, J., Parrish, D. D., Pszenny, A. A. P., $5 \quad$ Russell, R. P., Schlager, H., Seinfeld, J., Talbot, R., and Zbinden, R.: International Consortium for Atmospheric Research on Transport and Transformation (ICARTT): North America to Europe - Overview of the 2004 summer field study, J. Geophys. Res., 111, D23S01, doi:10.1029/2006JD007829, 2006.

Gerbig, C., Schmitgen, S., Kley, D., Volz-Thomas, A., Dewey, K., and Haaks, D.: An improved fast-response vacuum-UV resonance fluorescence CO instrument, J. Geophys. Res. Atmos., 104, 1699-1704, 1999.

Green, T. J., Reeves, C. E., Brough, N., Edwards, G. D., Monks, P. S., and Penkett, S. A.: Airborne measurements of peroxy radicals using the PERCA technique, J. Environ. Monitor., 5, 75-83, 2003.

Green, T. J., Reeves, C. E., Flemming, Z. L., Brough, N., Rickard, A. R., Bandy, B. J., Monks, P. S., and Penkett, S. A.: An improved dual channel PERCA instrument for atmospheric measurements of peroxy radicals, J. Env. Monitor., 8, 530-536, 2006.

Hanke, M., Uecker, J., Reiner, T., and Arnold, F.: Atmospheric peroxy radicals: ROXMAS, a new mass-spectrometric methodology for speciated measurements of $\mathrm{HO}_{2}$ and Sigma $\mathrm{RO}_{2}$ and $20 \quad$ first results, Int. J. Mass Spectrom., 213, 91-99, 2002.

Heard, D. E. and Pilling, M. J.: Measurement of $\mathrm{OH}$ and $\mathrm{HO}_{2}$ in the Troposphere, Chem. Rev., 103, 5163-5198, 2003.

Jaegle, L., Jacob, D. J., Brune, W. H., Faloona, I., Tan, D., Heikes, B. G., Kondo, Y., Sachse, G. W., Anderson, B., Gregory, G. L., Singh, H. B., Pueschel, R., Ferry, G., Blake, D. R., and Shetter, R. E.: Photochemistry of $\mathrm{HO}_{\mathrm{x}}$ in the upper troposphere at northern midlatitudes, J. Geophys. Res. Atmos., 105, 3877-3892, 2000.

Junkerman, W., Platt, U., and Volz-Thomas, A.: A Photoelectric Detector for the Measurement of Photolysis Frequencies of Ozone and other Atmospheric Molecules, J. Atmos. Chem., 8, 203-227, 1989.

30 Lewis, A. C., Watson, N., Evans, M. J., Methven, J., Lee, J. D., Hopkins, J. R., Purvis, R. M., Arnold, S. R., McQuaid, J. B., Whalley, L. K., Pilling, M. J., Heard, D. E., Monks, P. S., Parker, A. E., Reeves, C. E., Oram, D. E., Mills, G., Bandy, B. J., Stewart, D., Coe, H., Williams, P., and Crozier, J.: Chemical composition observed over the mid-Atlantic and the

\section{Peroxy radicals and ozone \\ photochemistry in air masses}

A. E. Parker et al.

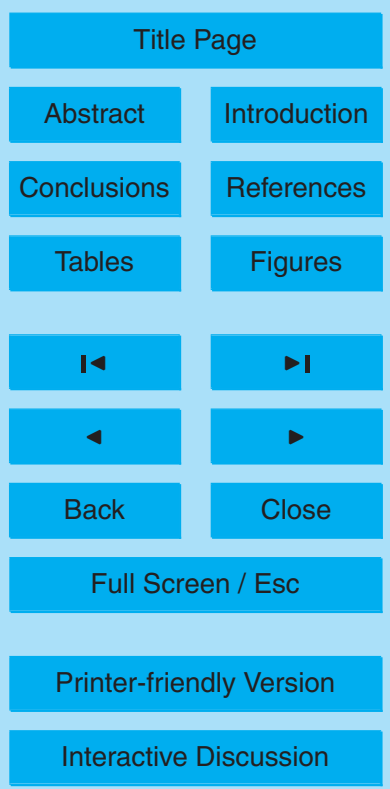


detection of pollution signatures far from source regions, J. Geophys. Res., 112, D10S39, doi:10.1029/2006JD007584, 2006.

Li, Q. B., Jacob, D. J., Bey, I., Palmer, P. I., Duncan, B. N., Field, B. D., Martin, R. V., Fiore, A. M., Yantosca, R. M., Parrish, D. D., Simmonds, P. G., and Oltmans, S. J.: Transatlantic transport 5 of pollution and its effects on surface ozone in Europe and North America, J. Geophys. Res. Atmos., 107(D13), 4166, doi:10.1029/2001JD001422, 2002.

Liu, S. C., Trainer, M., Fehsenfeld, F. C., Parrish, D. D., Williams, E. J., Fahey, D. W., Hubler, G., and Murphy, P. C.: Ozone Production in the Rural Troposphere and the Implications for Regional and Global Ozone Distributions, J. Geophys. Res. Atmos., 92, 4191-4207, 1987. Springer-Verlag, Heidelberg, 1-26, 1998.

Methven, J., Arnold, S. R., Stohl, A., Evans, M. J., Avery, M., Law, K., Lewis, A. C., Monks, P. S., Parrish, D. D., Reeves, C. E., Schlager, H., Atlas, E., Blake, D. R., Coe, H., Crosier, J., Flocke, F. M., Holloway, J. S., Hopkins, J. R., McQuaid, J., Purvis, R., Rappengluck, B., Singh, H. B., Watson, N. M., Whalley, L. K., and Williams, P. I.: Establishing Lagrangian connections between observations within air masses crossing the Atlantic during the International Consortium for Atmospheric Research on Transport and Transformation experiment, J. Geophys. Res. Atmos., 111(21), D23s62, doi:10.1029/2006jd007540, 2006.

Mihelcic, D., Holland, F., Hofzumahaus, A., Hoppe, L., Konrad, S., Musgen, P., Patz, H. W., Schafer, H. J., Schmitz, T., Volz-Thomas, A., Bachmann, K., Schlomski, S., Platt, U., Geyer, A., Alicke, B., and Moortgat, G. K.: Peroxy radicals during BERLIOZ at Pabstthum: Measurements, radical budgets and ozone production, J. Geophys. Res. Atmos., 108(D4), 8254, doi:10.1029/2001JD001014, 2003.

Mihele, C. M. and Hastie, D. R.: The sensitivity of the radical amplifier to ambient water vapour, Geophys. Res. Lett., 25, 1911-1913, 1998.

Mihele, C. M., Mozurkewich, M., and Hastie, D. R.: Radical loss in a chain reaction of CO and $\mathrm{NO}$ in the presence of water: Implications for the radical amplifier and atmospheric chemistry, Int. J. Chem. Kin., 31, 145-152, 1999.

Mihele, C. M. and Hastie, D. R.: Radical chemistry at a forested continental site: Results from the PROPHET 1997 campaign, J. Geophys. Res. Atmos., 108(D15), 4450, doi:10.1029/2002JD002888, 2003.

Monks, P. S., Carpenter, L. J., Penkett, S. A., Ayers, G. P., Gillett, R. W., Galbally, I. E., and Meyer, C. P.: Fundamental ozone photochemistry in the remote marine boundary layer: The

\section{Peroxy radicals and ozone \\ photochemistry in air masses}

A. E. Parker et al.

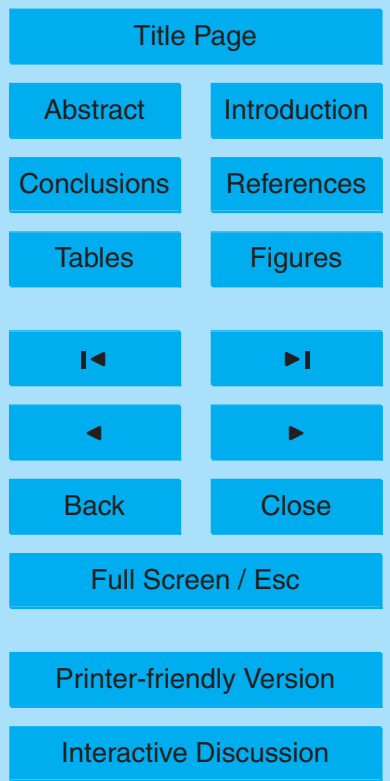


SOAPEX experiment, measurement and theory, Atmos. Environ., 32, 3647-3664, 1998.

Monks, P. S.: Gas-phase radical chemistry in the troposphere, Chem. Soc. Rev., 34, 376-395, 2005.

Northway, M. J., Gouw, J. A. d., Fahey, D. W., Gao, R. S., Warneke, C., Roberts, J. M., and

$5 \quad$ Flocke, F.: Evaluation of the role of heterogenous oxidation of alkenes in the detection of atmospheric acetaldehyde, Atmos. Environ., 38, 6017-6028, 2004.

Owen, R. C., Cooper, O. R., Stohl, A., and Honrath, R. E.: An analysis of the mechanisms of North American pollutant transport to the central North Atlantic lower free troposphere, J. Geophys. Res. Atmos., 111, D23S58, doi:10.1029/2006JD007062, 2006.

10 Penkett, S. A., Volz-Thomas, A., Parrish, D. D., Honrath, R. E., and Fehsenfeld, F. C.: Special section: North Atlantic Regional Experiment (NARE II) - Preface, J. Geophys. Res. Atmos., 103, 13353-13355, 1998.

Phillips, G. J.: Studies of Atmospheric Photochemistry in the European Troposphere, Ph.D. Thesis, University of Leicester, 2002.

Reeves, C. E. and Penkett, S. A.: Measurements of peroxides and what they tell us, Chem. Rev., 103, 5199-5218, 2003.

Reiner, T., Hanke, M., and Arnold, F.: Atmospheric peroxy radical measurements by ion molecule reaction mass spectrometry: A novel analytical method using amplifying chemical conversion to sulfuric acid, J. Geophys. Res. Atmos., 102, 1311-1326, 1997.

Salisbury, G., Rickard, A. R., Monks, P. S., Allan, B. J., Bauguitte, S., Penkett, S. A., Carslaw, N., Lewis, A. C., Creasey, D. J., Heard, D. E., Jacobs, P. J., and Lee, J. D.: Production of peroxy radicals at night via reactions of ozone and the nitrate radical in the marine boundary layer, J. Geophys. Res. Atmos., 106, 12669-12687, 2001.

Salisbury, G., Monks, P. S., Bauguitte, S., Bandy, B. J., and Penkett, S. A.: A seasonal comparison of the ozone photochemistry in clean and polluted air masses at Mace Head, Ireland, J. Atmos. Chem., 41, 163-187, 2002.

Sommariva, R., Haggerstone, A.-L., Carpenter, L. J., Carslaw, N., Creasey, D. J., Heard, D. E., Lee, J. D., Lewis, A. C., Pilling, M. J., and Zádor, J.: $\mathrm{OH}$ and $\mathrm{HO}_{2}$ chemistry in clean marine air during SOAPEX-2, Atmos. Chem. Phys., 4, 839-856, 2004,

$30 \quad$ http://www.atmos-chem-phys.net/4/839/2004/.

Stohl, A. and Trickl, T.: A textbook example of long-range transport: Simultaneous observation of ozone maxima of stratospheric and North American origin in the free troposphere over Europe, J. Geophys. Res. Atmos., 104, 30 445-30 462, 1999.

\section{Peroxy radicals and ozone \\ photochemistry in air masses}

A. E. Parker et al.

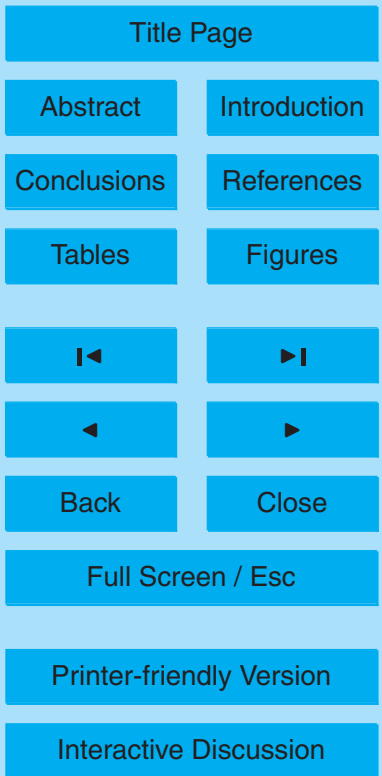

18819 
Stohl, A., Forster, C., Frank, A., Seibert, P., and Wotawa, G.: Technical Note: The Lagrangian particle dispersion model FLEXPART version 6.2, Atmos. Chem. Phys., 5, 2461-2474, 2005, http://www.atmos-chem-phys.net/5/2461/2005/.

Volz-Thomas, A., Lerner, A., Patz, H. S., Schultz, M., McKenna, D., Schmitt, R., Madronich, S., 5 and Roth, E.: Airborne Measurements of the Photolysis of $\mathrm{NO}_{2}$, J. Geophys. Res. Atmos., 101, 18613-18627, 1996.

Wild, O. and Akimoto, H.: Intercontinental transport of ozone and its precursors in a threedimensional global CTM, J. Geophys. Res. Atmos., 106, 27 729-27 744, 2001.

Zanis, P., Monks, P. S., Schuepbach, E., Carpenter, L. J., Green, T. J., Mills, G. P., Bauguitte, S., and Penkett, S. A.: In situ ozone production under free tropospheric conditions during FREETEX '98 in the Swiss Alps, J. Geophys. Res. Atmos., 105, 24 223-24 234, 2000.

\section{ACPD}

9, 18793-18838, 2009

\section{Peroxy radicals and ozone \\ photochemistry in air masses}

A. E. Parker et al.

\section{Title Page}

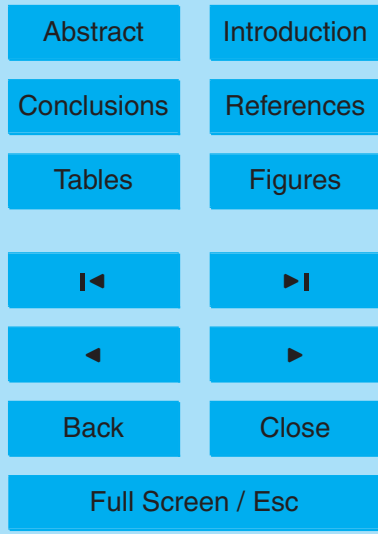

Printer-friendly Version

Interactive Discussion 
Table 1. Mean $\left[\mathrm{HO}_{2}+\sum_{i} \mathrm{R}_{i} \mathrm{O}_{2}\right]$ binned into differing air masses, along with mean ozone mixing ratios and number of points per bin.

\begin{tabular}{lccc}
\hline & $\begin{array}{c}\text { Marine Air } \\
(\mathrm{O} 3<40 \mathrm{ppbv}, \mathrm{CO}<90 \mathrm{ppbv})\end{array}$ & $\begin{array}{c}\left.\mathrm{HO}_{2}+\mathrm{RO}_{2}\right] / \mathrm{pptv} \\
\text { Alaskan Fire Plume } \\
(\mathrm{CO}>250 \mathrm{ppbv})\end{array}$ & All Others \\
\hline Mean & 19 & 36 & 41 \\
Standard Deviation & 13 & 18 & 19 \\
Median & 16 & 37 & 42 \\
10th Percentile & 5 & 12 & 15 \\
90th Percentile & 38 & 59 & 65 \\
Mean Ozone /ppbv & 26 & 64 & 64 \\
Number of Points & 637 & 35 & 1797 \\
\hline
\end{tabular}

\section{ACPD}

9, 18793-18838, 2009

\section{Peroxy radicals and ozone \\ photochemistry in air masses}
A. E. Parker et al.

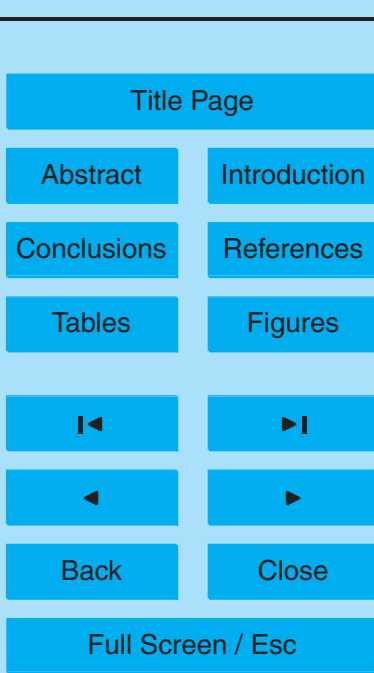

Printer-friendly Version

Interactive Discussion 
Table 2. VOCs and measurement techniques used to calculate VOC reactivity.

\begin{tabular}{|c|c|c|c|}
\hline Compound & Measurement Technique & Institution & $\begin{array}{l}\text { Reference for rate constant } \\
\text { for reaction with } \mathrm{OH}\end{array}$ \\
\hline carbon monoxide & $\begin{array}{l}\text { Aero-Laser Gmbh AL5002 } \\
\text { Fast Carbon Monoxide (CO) Monitor }\end{array}$ & FAAM & (Atkinson et al., 2004) \\
\hline methane $e^{b}$ & $\mathrm{n} / \mathrm{a}$ & $\mathrm{n} / \mathrm{a}$ & (Atkinson et al., 2006) \\
\hline ethane & Dual-channel GC-FID of WAS & York & (Atkinson et al., 2006) \\
\hline ethene & Dual-channel GC-FID of WAS & York & (Atkinson et al., 2005) \\
\hline propane & Dual-channel GC-FID of WAS & York & (Atkinson et al., 2006) \\
\hline propene & Dual-channel GC-FID of WAS & York & (Atkinson et al., 2006) \\
\hline iso-butane & Dual-channel GC-FID of WAS & York & (Atkinson, 2003) \\
\hline n-butane & Dual-channel GC-FID of WAS & York & (Atkinson et al., 2006) \\
\hline acetylene & Dual-channel GC-FID of WAS & York & \\
\hline trans-2-butene & Dual-channel GC-FID of WAS & York & (Atkinson, 1986) \\
\hline 1-butene & Dual-channel GC-FID of WAS & York & (Atkinson, 1986) \\
\hline iso-butene & Dual-channel GC-FID of WAS & York & (Atkinson, 1986) \\
\hline cis-2-butene & Dual-channel GC-FID of WAS & York & (Atkinson, 1986) \\
\hline 1,2-butadiene & Dual-channel GC-FID of WAS & York & (Atkinson, 1986) $^{c}$ \\
\hline 1,3-butadiene & Dual-channel GC-FID of WAS & York & (Atkinson, 1986) \\
\hline propyne & Dual-channel GC-FID of WAS & York & (Boodaghians et al., 1987) \\
\hline isoprene & Dual-channel GC-FID of WAS & York & (Atkinson, 1986) \\
\hline acetaldehyde & Dual-channel GC-FID of WAS & York & (Atkinson et al., 2006) \\
\hline methanol & Dual-channel GC-FID of WAS & York & (Atkinson et al., 2006) \\
\hline acetone & Dual-channel GC-FID of WAS & York & (Atkinson et al., 2006) \\
\hline formaldehyde & Hantschz fluorescence & UEA & (Atkinson et al., 2006) \\
\hline
\end{tabular}

\section{Peroxy radicals and ozone \\ photochemistry in air masses}

A. E. Parker et al.

a (Gerbig et al., 1999)

${ }^{\mathrm{b}}$ methane was set to a constant $1750 \mathrm{ppbv}$

${ }^{c}$ rate for $\mathrm{OH}+1,3$-butadiene used

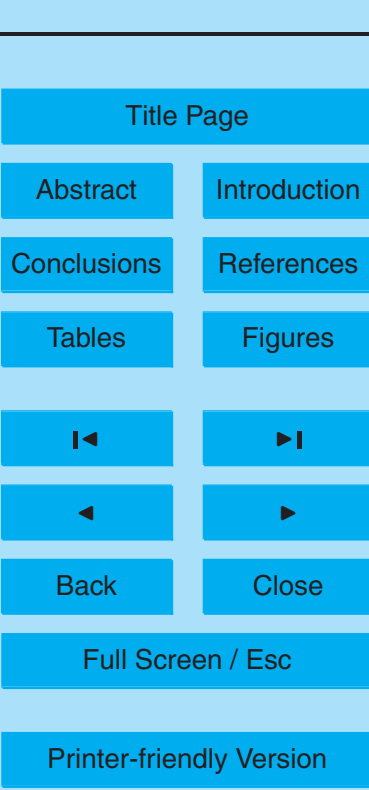

Interactive Discussion 


\section{ACPD}

9, 18793-18838, 2009

\section{Peroxy radicals and ozone}

photochemistry in air masses

Table 3. $\mathrm{N}\left(\mathrm{O}_{3}\right)$ binned into differing air masses.

\begin{tabular}{lccr}
\hline & $\begin{array}{c}\text { Marine Air } \\
\left(\mathrm{O}_{3}<40 \mathrm{ppbv}, \mathrm{CO}<90 \mathrm{ppbv}\right)\end{array}$ & $\begin{array}{c}\mathrm{N}\left(\mathrm{O}_{3}\right) / \mathrm{ppbv}^{-1} \\
\text { Alaskan Fire Plume } \\
(\mathrm{CO}>250 \mathrm{ppbv})\end{array}$ & All others \\
\hline Median & -0.16 & 1.46 & -0.09 \\
Standard Deviation & 0.78 & 0.76 & 1.32 \\
10th Percentile & -0.61 & 0.40 & -0.58 \\
90th Percentile & 0.48 & 1.94 & 1.18 \\
\hline
\end{tabular}

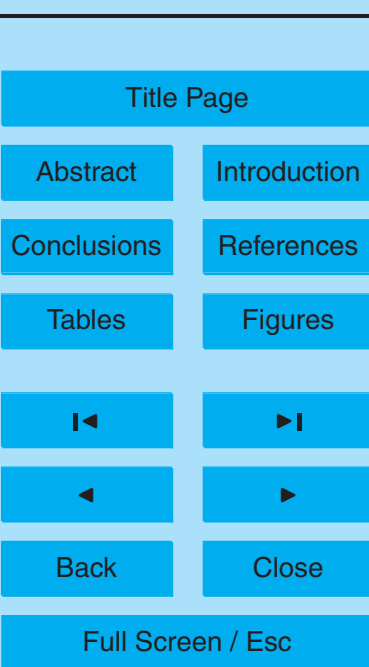

Printer-friendly Version

Interactive Discussion 


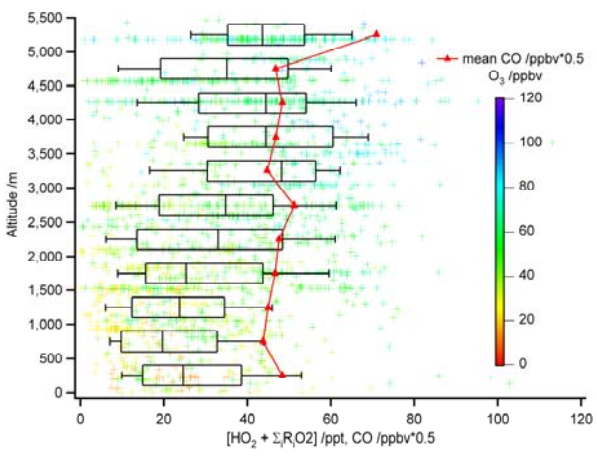

\section{ACPD}

9, 18793-18838, 2009

\section{Peroxy radicals and ozone \\ photochemistry in air masses}

A. E. Parker et al.

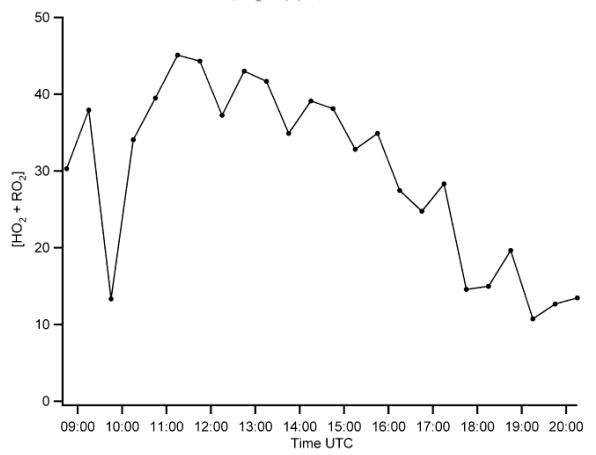

Title Page

Abstract

Conclusions

Tables

14

4

Back

Full Screen / Esc

Printer-friendly Version

Fig. 1. (a) peroxy radicals binned by altitude and coloured by ozone levels. The box indicates 25th percentile, median and 75th percentile whilst the whiskers indicate 10th and 90th percentiles. Crosses indicate individual data points. Red triangles indicate mean $\mathrm{CO}$ binned by altitude and (b) median peroxy radicals binned by time UTC averaged for all flights.

Interactive Discussion 


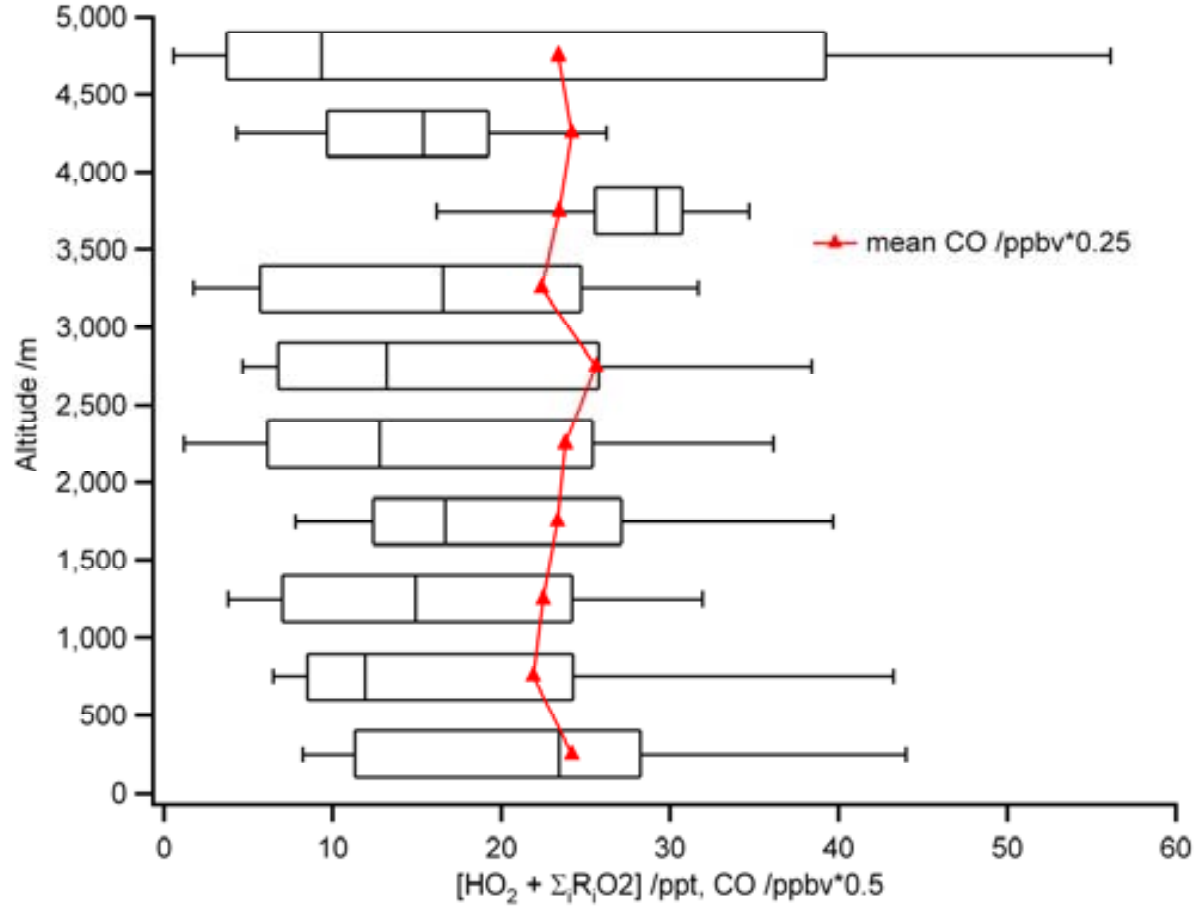

Fig. 2. Altitude profile of peroxy radicals in air designated of marine origin $\left(\mathrm{O}_{3}<40 \mathrm{ppbv}\right.$, $\mathrm{CO}<90 \mathrm{ppbv}$ ). The box indicates 25th percentile, median and 75th percentile whilst the whiskers indicate 10th and 90th percentiles. Red triangles indicate mean CO binned by altitude.
ACPD

9, 18793-18838, 2009

\section{Peroxy radicals and ozone \\ photochemistry in air masses}

A. E. Parker et al.

\section{Title Page}

\section{Abstract}

Introduction

Conclusions

References

Tables

Figures

14

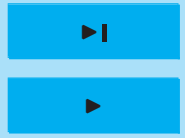

Back

Close

\section{Full Screen / Esc}

Printer-friendly Version

Interactive Discussion 

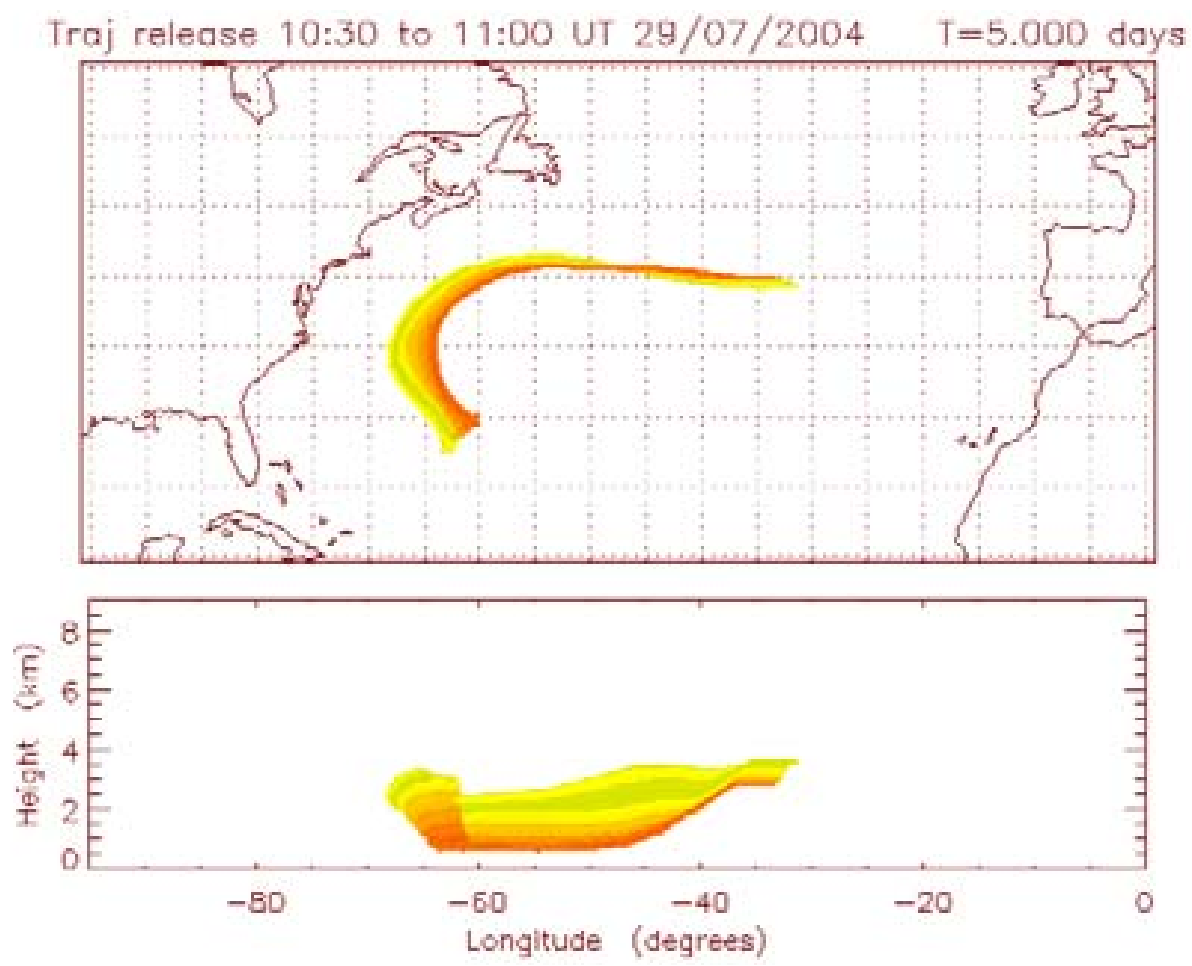

Fig. 3. Back trajectories for section of flight B036 on 29 July 2004 showing marine background air with elevated peroxy radical levels over median coloured by pressure $5 \mathrm{~d}$ before arrival.

\section{ACPD}

9, 18793-18838, 2009

\section{Peroxy radicals and ozone \\ photochemistry in air masses}

A. E. Parker et al.

Title Page

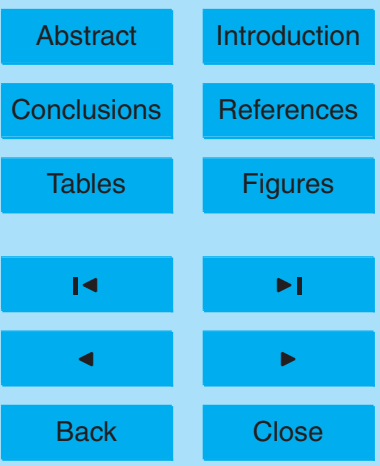

Full Screen / Esc

Printer-friendly Version

Interactive Discussion 


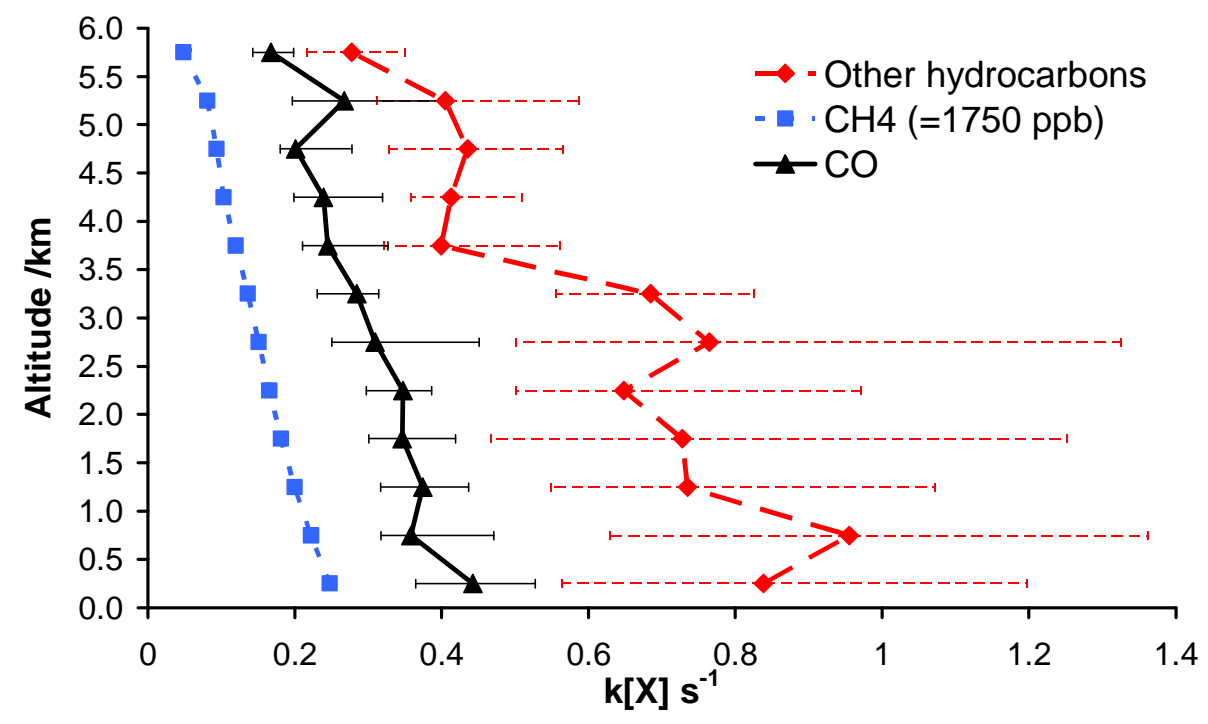

Fig. 4. Relative contributions of methane, carbon monoxide, and other non-methyl hydrocarbons to $\mathrm{OH}$ reactivity. Points represent median values and error bars 25 th and 75 th percentiles. $[X]$ is in molecules $\mathrm{cm}^{-3}$.

\section{ACPD}

9, 18793-18838, 2009

\section{Peroxy radicals and ozone \\ photochemistry in air masses}
A. E. Parker et al.

\section{Title Page}

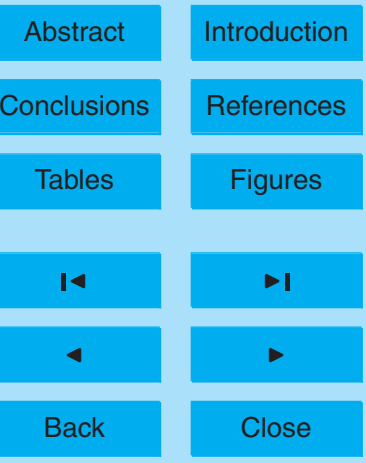

Full Screen / Esc

Printer-friendly Version

Interactive Discussion 


\section{ACPD}

9, 18793-18838, 2009

\section{Peroxy radicals and ozone \\ photochemistry in air masses}
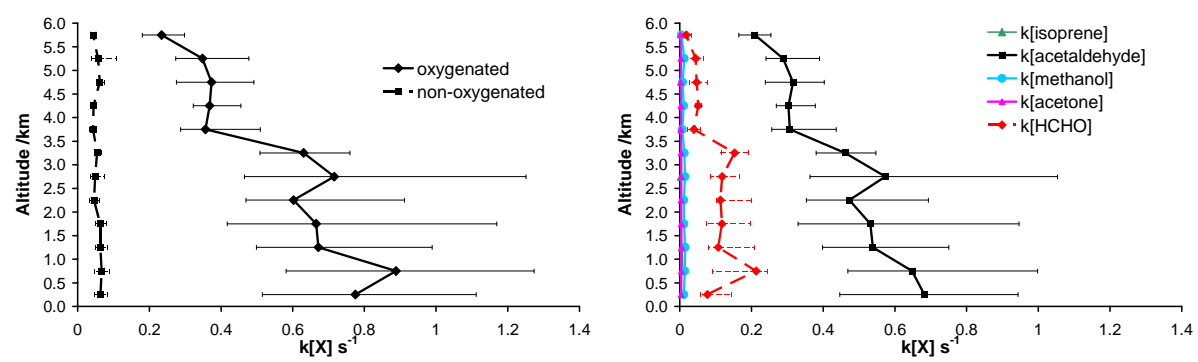

A. E. Parker et al.

Fig. 5. (a) relative contributions of oxygenated and non-oxygenated C2-C4 non-methyl hydrocarbons to $\mathrm{OH}$ reactivity and (b) contribution of various oxygenates to $\mathrm{OH}$ reactivity. Points represent median values and error bars 25 th and 75 th percentiles. $[X]$ is in molecules $\mathrm{cm}^{-3}$.

Title Page

Abstract

Introduction

Conclusions

References

Tables

Figures

14

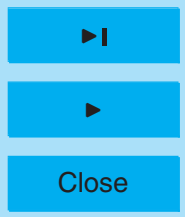

Back

Full Screen / Esc

Printer-friendly Version

Interactive Discussion 


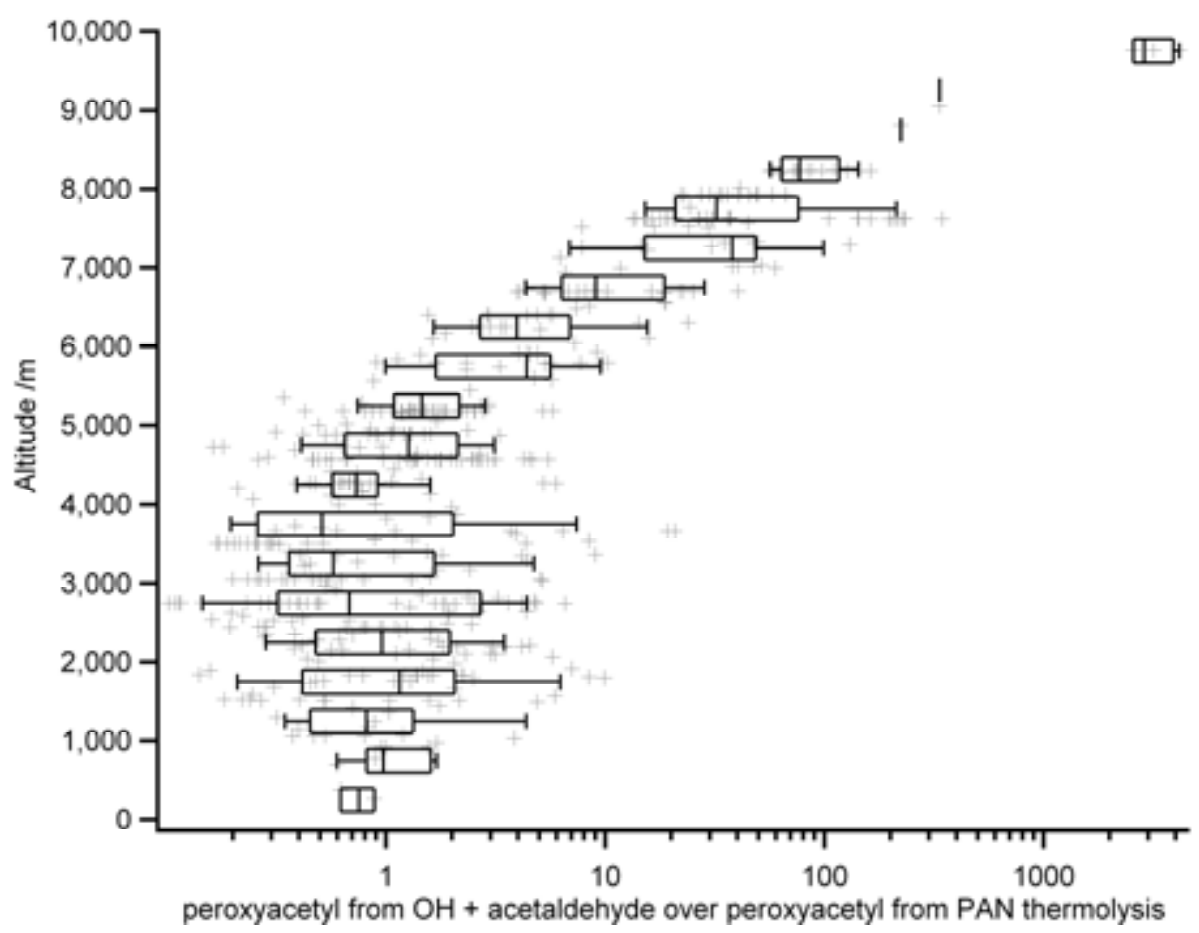

Fig. 6. Ratio of peroxyacetyl radicals formed from reaction of $\mathrm{OH}$ and acetaldehyde to peroxyacetyl radicals formed from PAN thermal decomposition binned by altitude. The box indicates 25th percentile, median and 75th percentile whilst the whiskers indicate 10th and 90th percentiles.

\section{ACPD}

9, 18793-18838, 2009

\section{Peroxy radicals and ozone \\ photochemistry in air masses}

A. E. Parker et al.

\section{Title Page}

\section{Abstract}

Conclusions

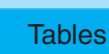

14

$<$

Back

Full Screen / Esc

Printer-friendly Version

Interactive Discussion 


\section{ACPD}

9, 18793-18838, 2009

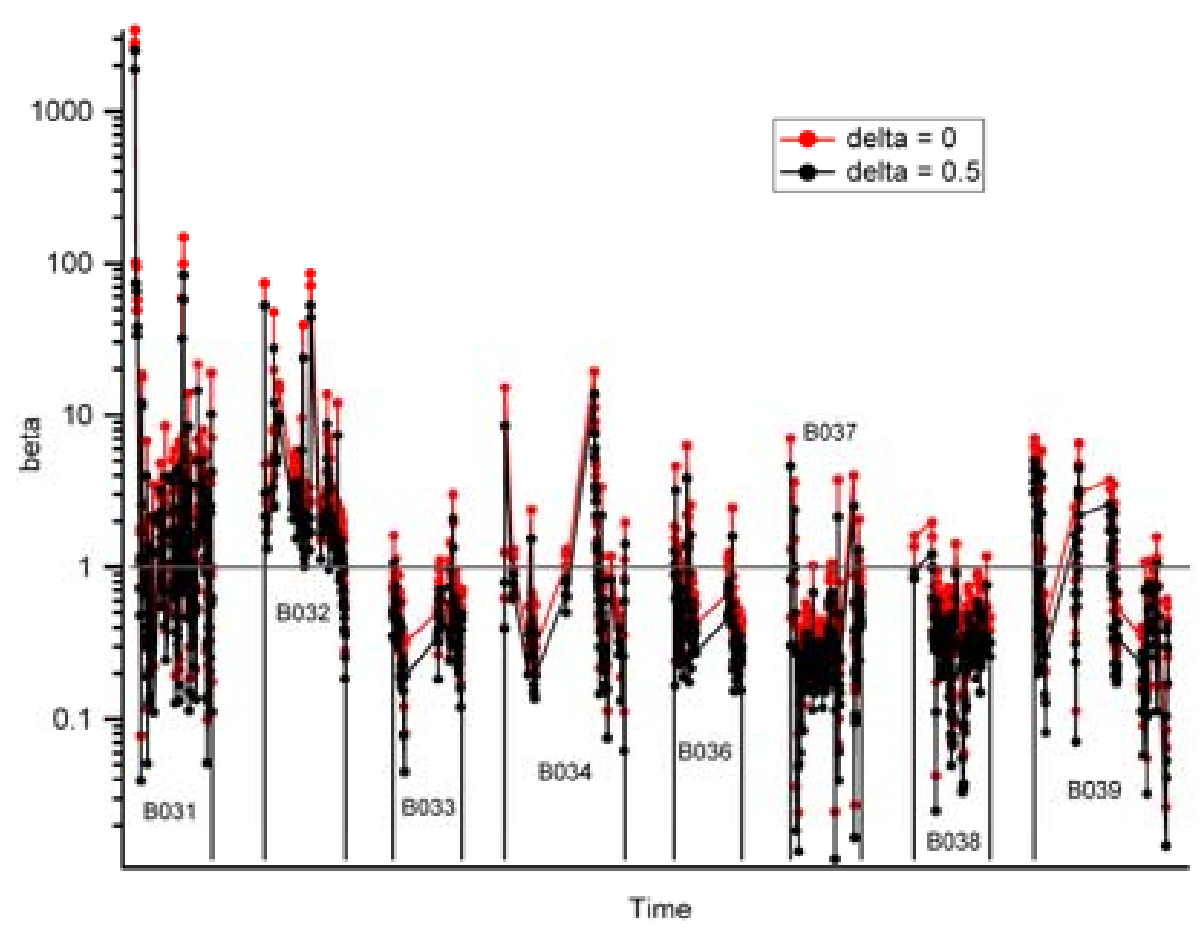

Fig. 7. Time series showing $\beta$ values with $\delta=0$ and $\delta=0.5$ for flights $\mathrm{B} 031$ to $\mathrm{B} 034$ and $\mathrm{B} 036$ to B039.

\section{Peroxy radicals and ozone}

photochemistry in air masses
A. E. Parker et al.

\section{Title Page}

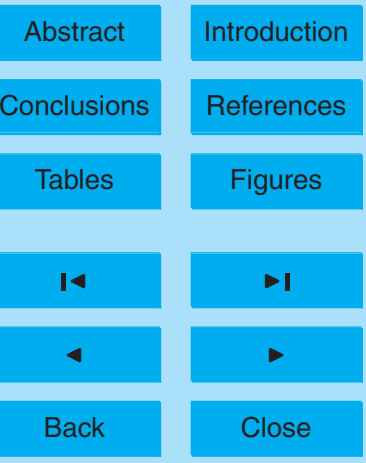

Full Screen / Esc

Printer-friendly Version

Interactive Discussion 


\section{ACPD}

9, 18793-18838, 2009

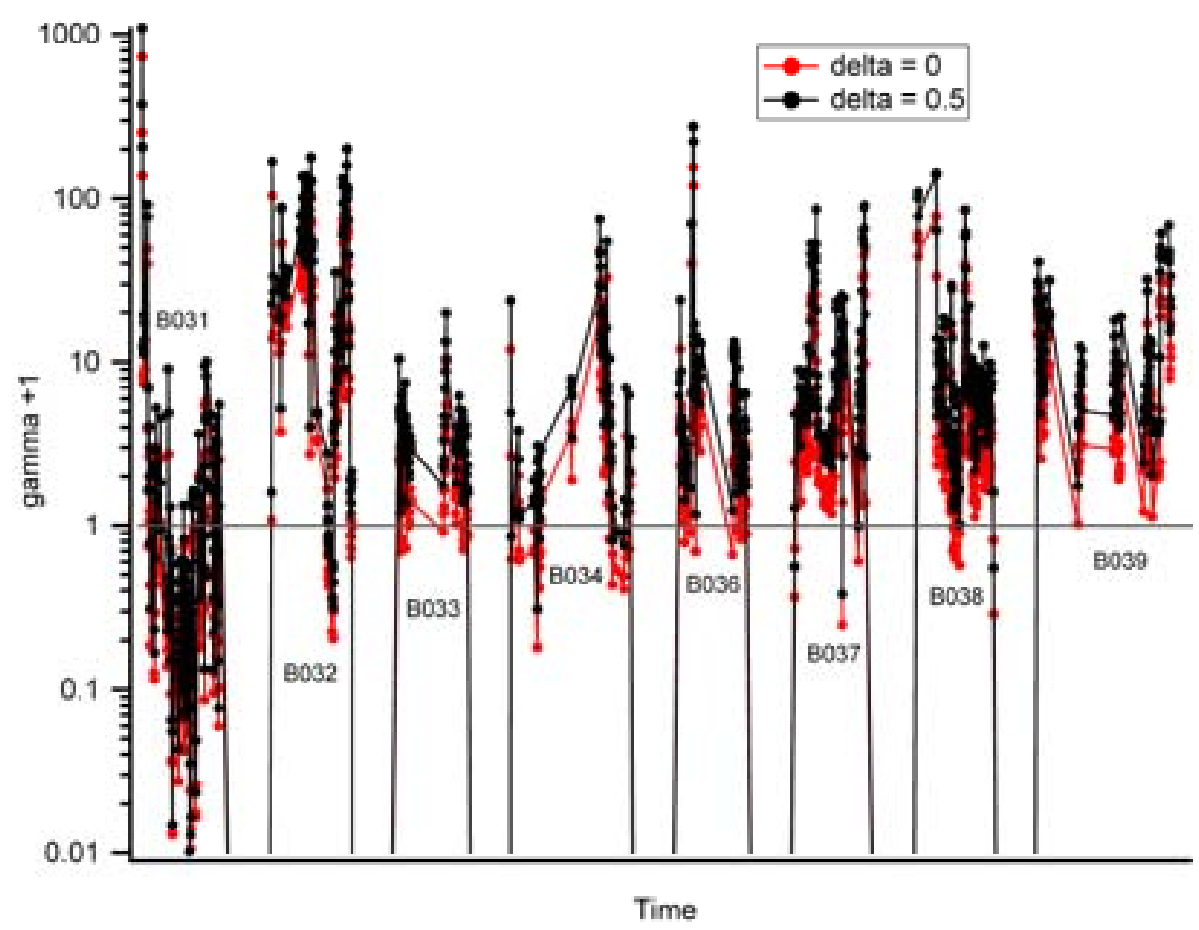

Fig. 8. Time series showing $\gamma+1$ values with $\delta=0$ and $\delta=0.5$ for flights $\mathrm{B} 031$ to $\mathrm{B} 034$ and $\mathrm{B} 036$ to B039.

\section{Peroxy radicals and ozone}

photochemistry in air masses
A. E. Parker et al.

\section{Title Page}

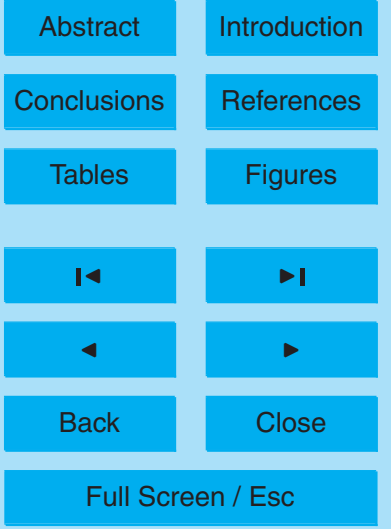

Printer-friendly Version

Interactive Discussion 


\section{ACPD}

9, 18793-18838, 2009

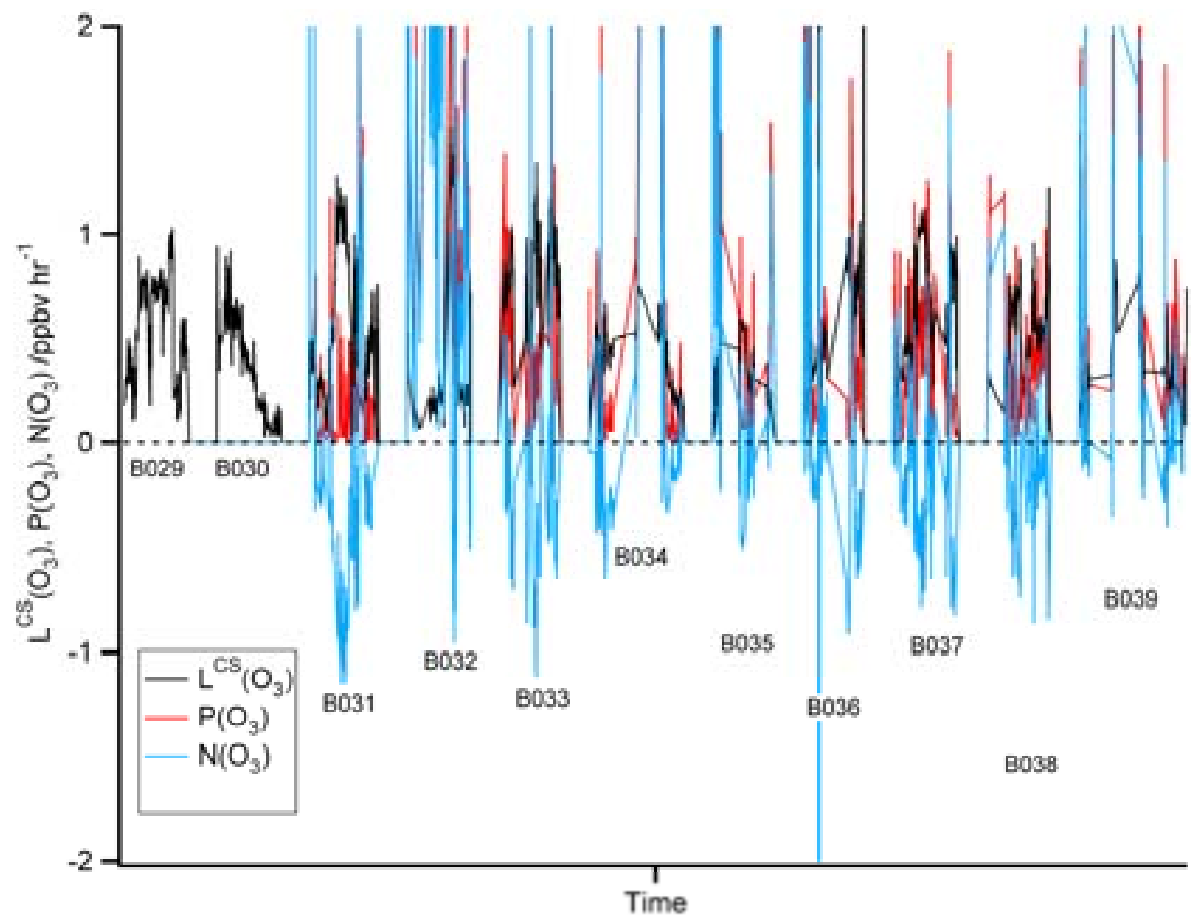

\section{Peroxy radicals and ozone}

photochemistry in air masses
A. E. Parker et al.

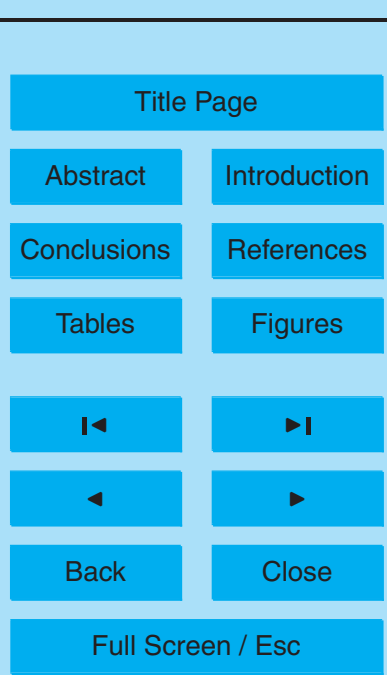

Fig. 9. Timeseries showing $\mathrm{P}\left(\mathrm{O}_{3}\right), \mathrm{L}^{\mathrm{CS}}\left(\mathrm{O}_{3}\right)$ and $\mathrm{N}\left(\mathrm{O}_{3}\right)$ for all flights.

Printer-friendly Version

Interactive Discussion 

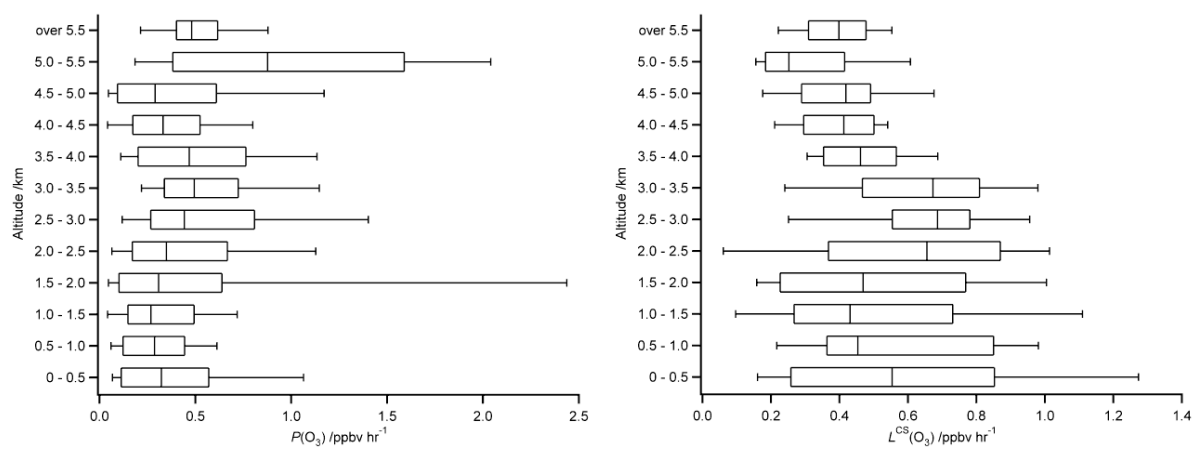

ACPD

9, 18793-18838, 2009
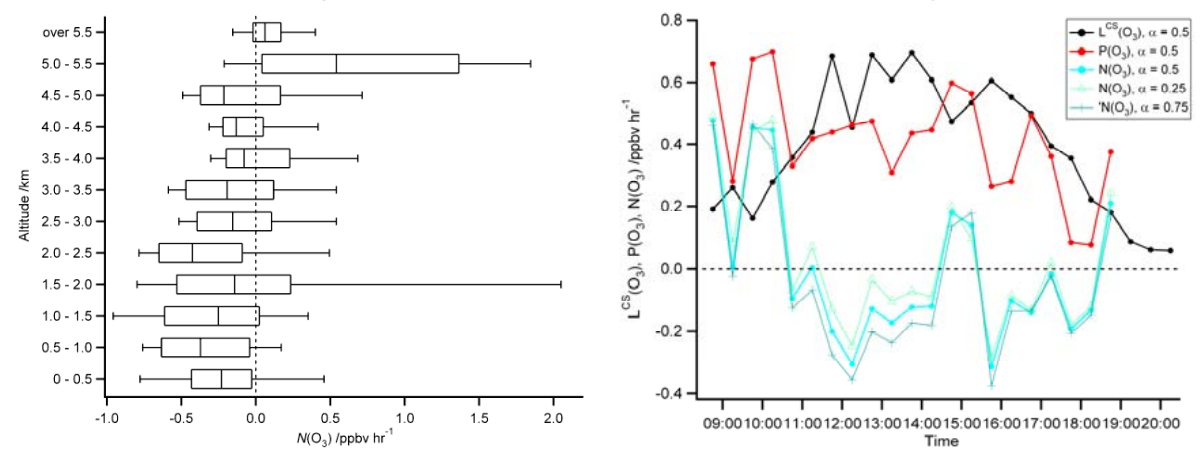

\section{Peroxy radicals and ozone \\ photochemistry in air masses}
A. E. Parker et al.

\section{Title Page}

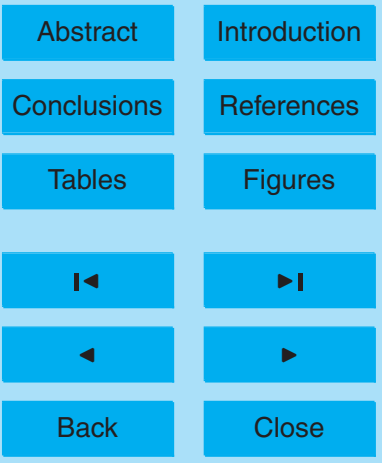

Fig. 10. (a) ozone production rate (b) ozone loss rate (c) net ozone production rate binned with altitude and (d) median ozone production, loss and net production rates. In (a), (b), and (c) the box represents the 25th, median and 75th percentiles and the whiskers denote 10th and 90th percentiles. In (d) net ozone production is shown for $\alpha=0.25,0.5$ and 0.75 .

Full Screen / Esc

Printer-friendly Version

Interactive Discussion 


\section{ACPD}

9, 18793-18838, 2009

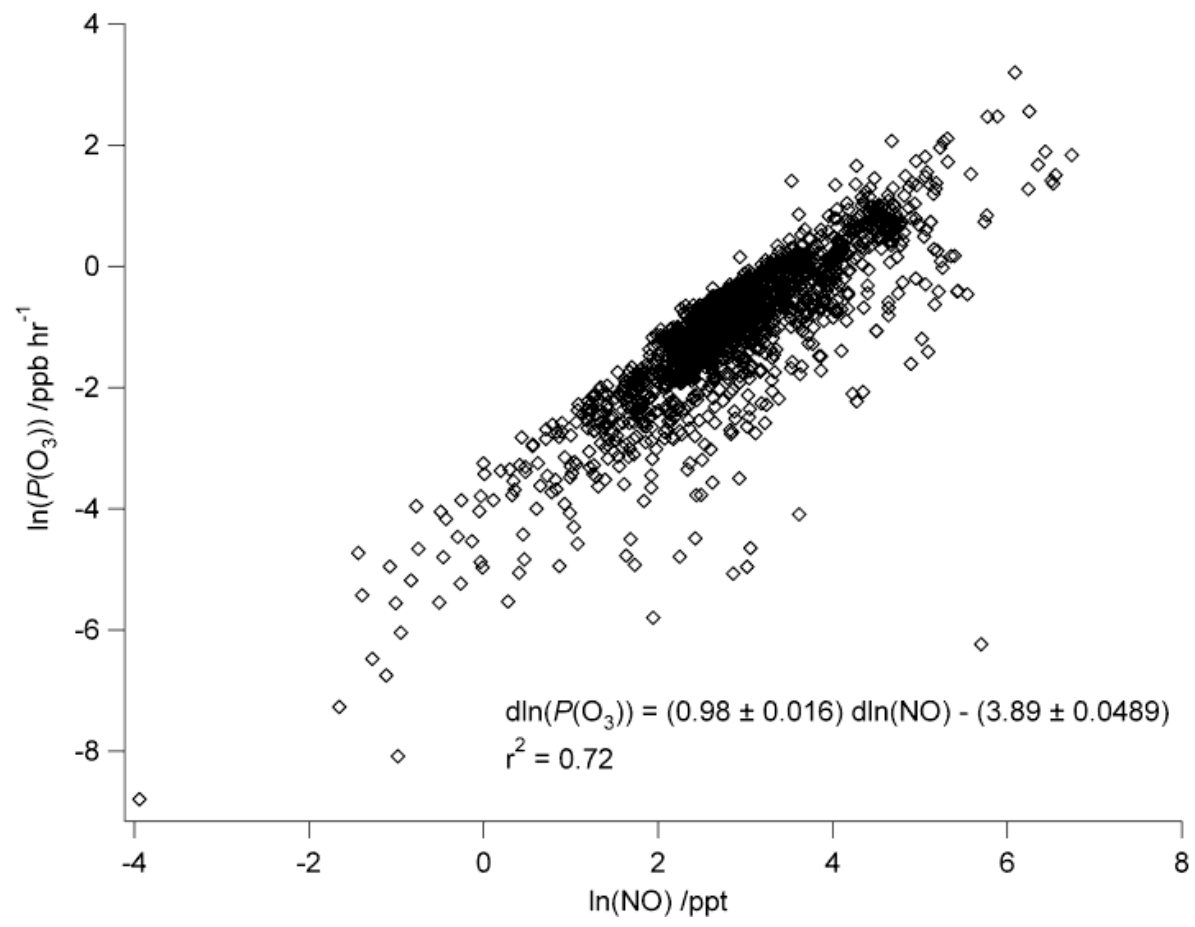

\section{Peroxy radicals and ozone}

photochemistry in air masses

A. E. Parker et al.

Title Page

Abstract

Introduction

Conclusions

References

Tables

Figures

14

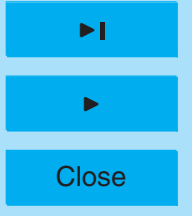

Back

Full Screen / Esc

Fig. 11. Correlation between $\ln \left(\mathrm{P}\left(\mathrm{O}_{3}\right)\right)$ and $\ln (\mathrm{NO})$.

Printer-friendly Version

Interactive Discussion 


\section{ACPD}

9, 18793-18838, 2009

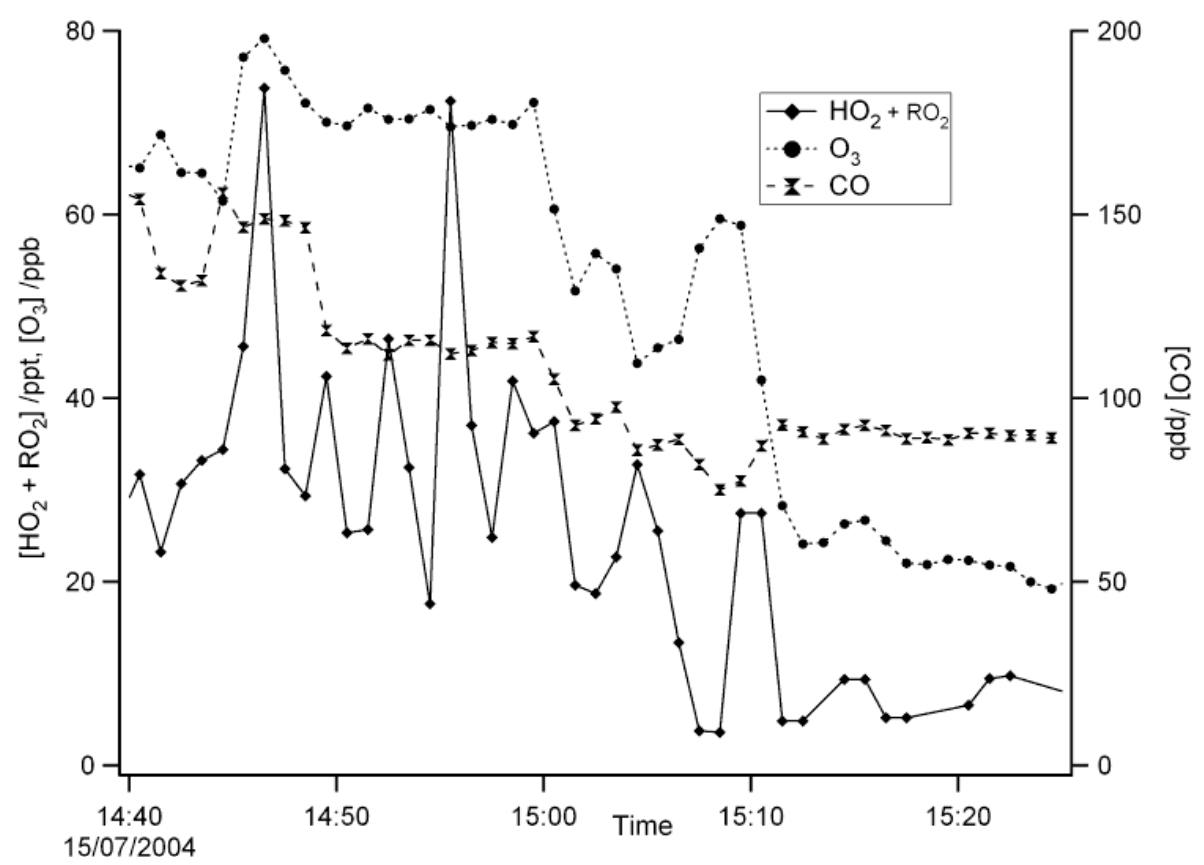

\section{Peroxy radicals and ozone}

photochemistry in air masses
A. E. Parker et al.

\section{Title Page}

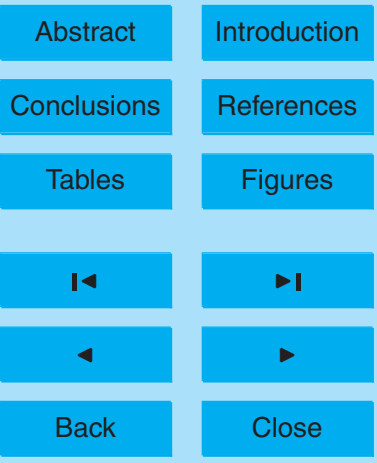

Full Screen / Esc 15 July 2004.

Printer-friendly Version

Interactive Discussion 


\section{ACPD}

9, 18793-18838, 2009

\section{Peroxy radicals and ozone \\ photochemistry in air masses}
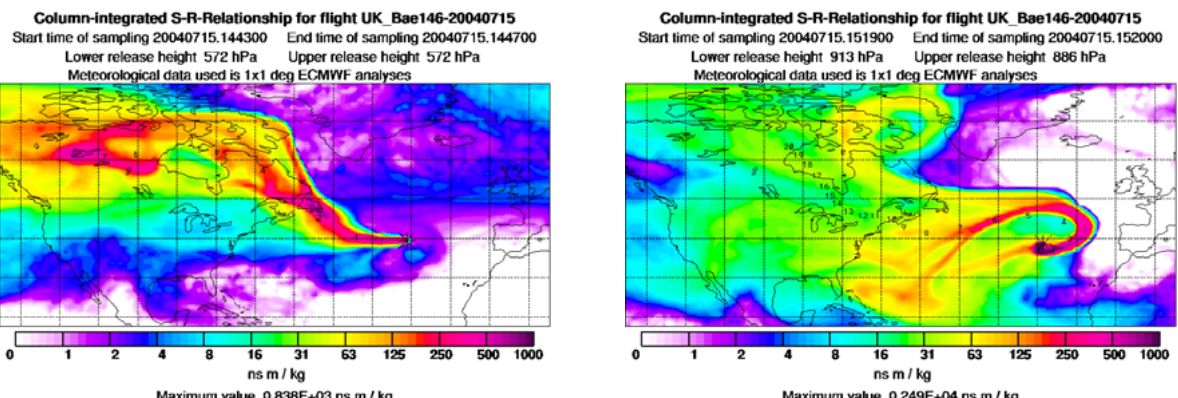

A. E. Parker et al.

Maximum value $0.838 \mathrm{E}+03 \mathrm{~ns} \mathrm{~m} / \mathrm{kg}$

Maximum value $0.249 \mathrm{E}+04 \mathrm{~ns} \mathrm{~m} / \mathrm{kg}$

Title Page

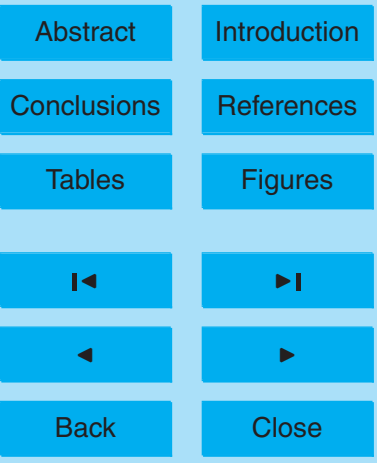

Full Screen / Esc

Printer-friendly Version

Interactive Discussion 


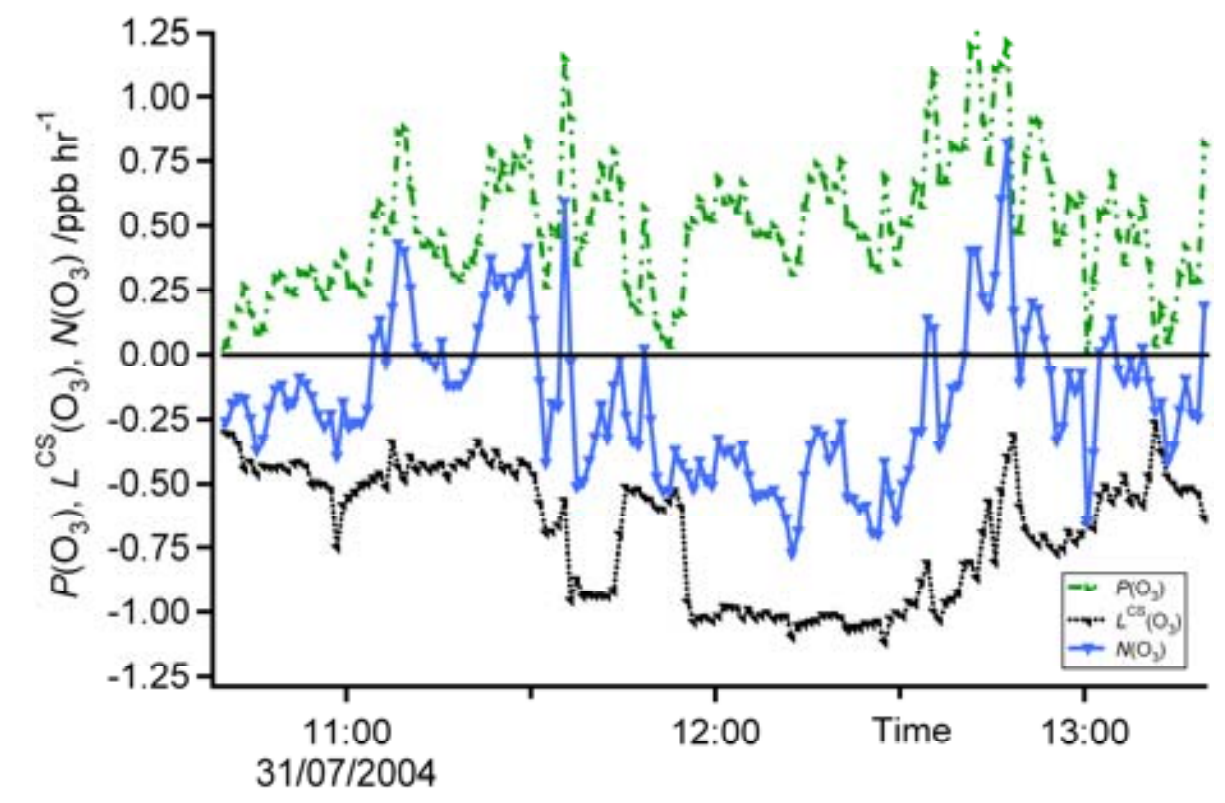

Fig. 14. Time series of ozone production rate, clear sky limited loss rate and net ozone production rate for a section of flight B037 on 31 July 2004.

\section{ACPD}

9, 18793-18838, 2009

\section{Peroxy radicals and ozone}

photochemistry in air masses
A. E. Parker et al.

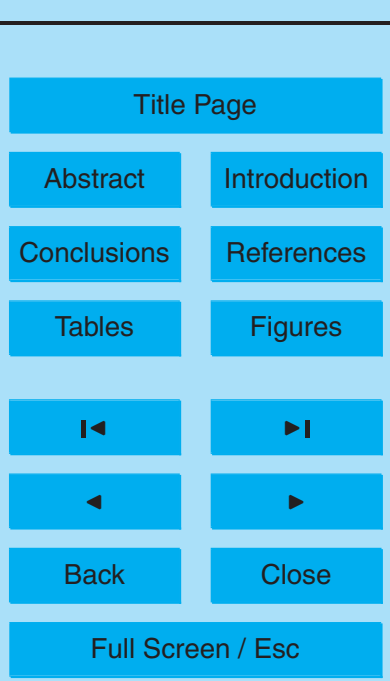

Printer-friendly Version

Interactive Discussion 

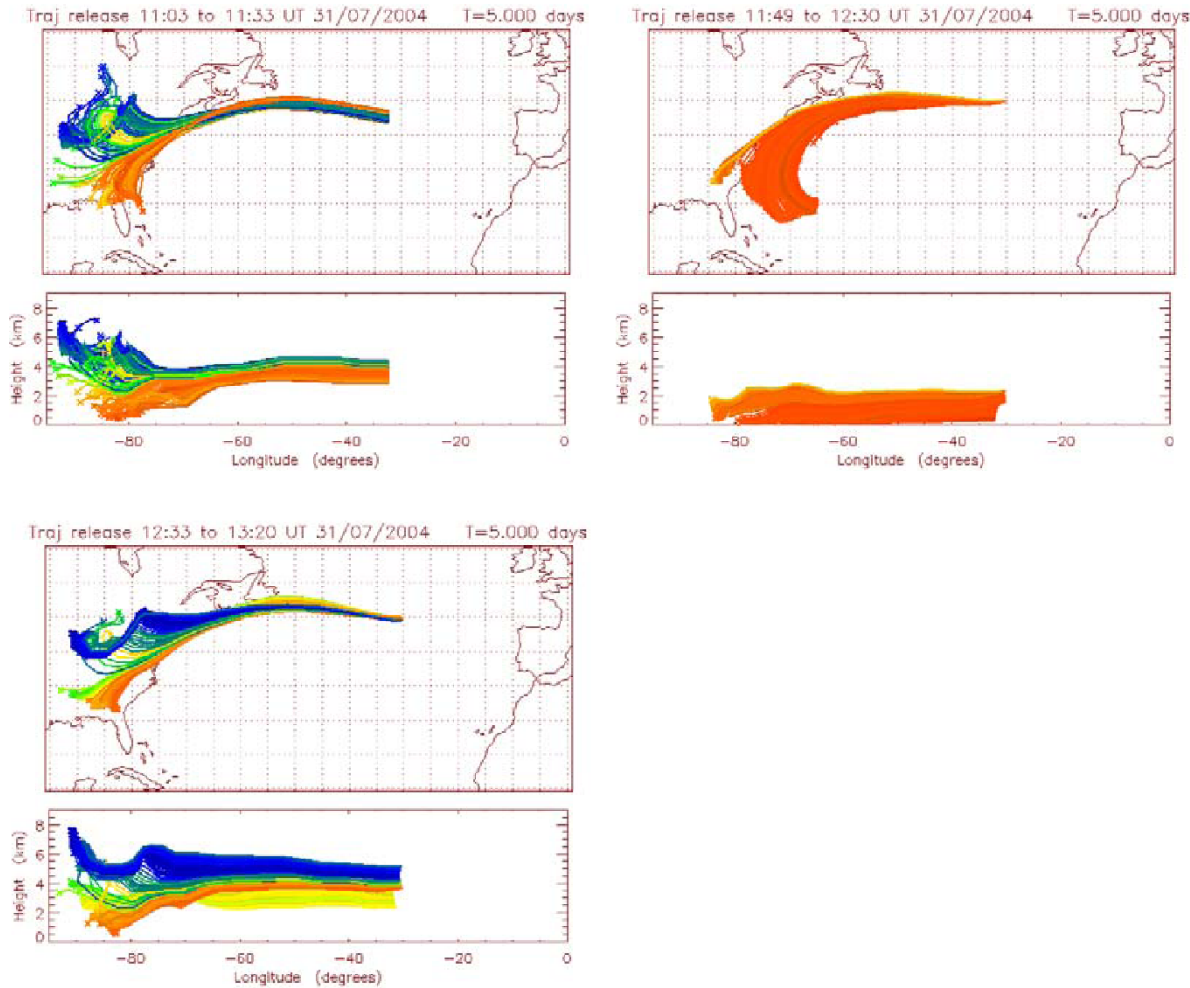

Fig. 15. Back trajectories showing air-mass origins for a section of flight B037 on 31 July 2004 coloured by pressure $5 \mathrm{~d}$ before arrival.

\section{ACPD}

9, 18793-18838, 2009

\section{Peroxy radicals and ozone}

photochemistry in air masses

A. E. Parker et al.

\section{Title Page}

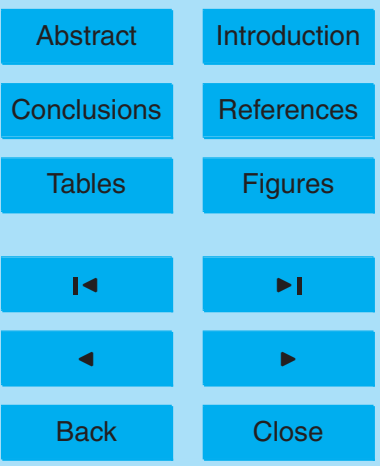

Full Screen / Esc

Printer-friendly Version

Interactive Discussion 